\title{
Oxidative Cleavage of Cellobiose by Lytic Polysaccharide Monooxygenase (LPMO)-Inspired Copper Complexes
}

Andrea. C. Neira, ${ }^{\dagger}$ Paulina R. Martínez-Alanis, ${ }^{\S}$ Gabriel Aullón, ${ }^{\S}{ }^{\S}$ Marcos Flores-Alamo, Paulino Zerón, ${ }^{\ddagger}$ Anna Company, ${ }^{\| \odot}$ Juan Chen, ${ }^{\perp}$ Johann B. Kasper, ${ }^{\perp}$ Wesley R. Browne, ${ }^{\perp}$ Ebbe Nordlander, and Ivan Castillo*, ${ }^{*}+0$

Instituto de Química and Facultad de Química, División de Estudios de Posgrado, Universidad Nacional Autónoma de México, Circuito Exterior, CU, 04510 Ciudad de México, México

${ }^{\S}$ Departament de Química Inorgànica i Orgànica and Institut de Química Teòrica i Computacional, Universitat de Barcelona, Martí i Franquès 1-11, 08028 Barcelona, Spain

"Institut de Química Computacional i Catàlisi (IQCC), Departament de Química, Universitat de Girona, C/ M. Aurèlia Capmany 69, 17003 Girona, Catalonia, Spain

${ }^{\perp}$ Molecular Inorganic Chemistry, Stratingh Institute for Chemistry, Faculty of Science and Health, University of Groningen, Nijenborgh 4, 9747AG Groningen, The Netherlands

${ }^{\#}$ Chemical Physics, Department of Chemistry, Lund University, Box 124, SE-221 00 Lund, Sweden

Supporting Information

ABSTRACT: The potentially tridentate ligand bis[(1-methyl2-benzimidazolyl)ethyl]amine (2BB) was employed to prepare copper complexes $\left[(2 \mathbf{B B}) \mathrm{Cu}^{\mathrm{I}}\right] \mathrm{OTf}$ and $[(\mathbf{2 B B})$ $\left.\mathrm{Cu}^{\mathrm{II}}\left(\mathrm{H}_{2} \mathrm{O}\right)_{2}\right](\mathrm{OTf})_{2}$ as bioinspired models of lytic polysaccharide copper-dependent monooxygenase (LPMO) enzymes. Solid-state characterization of $\left[(\mathbf{2 B B}) \mathrm{Cu}^{\mathrm{I}}\right] \mathrm{OTf}$ revealed a $\mathrm{Cu}(\mathrm{I})$ center with a $\mathrm{T}$-shaped coordination environment and metric parameters in the range of those observed in reduced LPMOs. Solution characterization of $\left[(\mathbf{2 B B}) \mathrm{Cu}^{\mathrm{II}}\left(\mathrm{H}_{2} \mathrm{O}\right)_{2}\right](\mathrm{OTf})_{2}$ indicates that $[(\mathbf{2 B B})$ $\left.\mathrm{Cu}^{\mathrm{II}}\left(\mathrm{H}_{2} \mathrm{O}\right)_{2}\right]^{2+}$ is the main species from $\mathrm{pH} 4$ to 7.5 ; above $\mathrm{pH} 7.5$, the hydroxo-bridged species $\left[\left\{(2 \mathrm{BB}) \mathrm{Cu}^{\mathrm{II}}\left(\mathrm{H}_{2} \mathrm{O}\right)_{x}\right\}_{2}(\mu\right.$ -

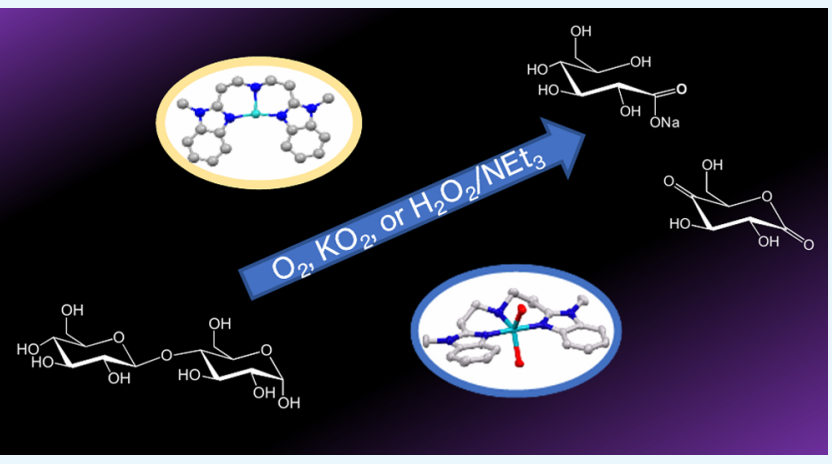
$\left.\mathrm{OH})_{2}\right]^{2+}$ is also present, on the basis of cyclic voltammetry and mass spectrometry. These observations imply that deprotonation of the central amine of $\mathrm{Cu}(\mathrm{II})$-coordinated $2 \mathrm{BB}$ is precluded, and by extension, amine deprotonation in the histidine brace of LPMOs appears unlikely at neutral $\mathrm{pH}$. The complexes $\left[(2 \mathbf{B B}) \mathrm{Cu}^{\mathrm{I}}\right] \mathrm{OTf}$ and $\left[(\mathbf{2 B B}) \mathrm{Cu}^{\mathrm{II}}\left(\mathrm{H}_{2} \mathrm{O}\right)_{2}\right](\mathrm{OTf})_{2}$ act as precursors for the oxidative degradation of cellobiose as a cellulose model substrate. Spectroscopic and reactivity studies indicate that a dicopper(II) side-on peroxide complex generated from $\left[(2 \mathrm{BB}) \mathrm{Cu}^{\mathrm{I}}\right] \mathrm{OTf} / \mathrm{O}_{2}$ or $\left[(2 \mathrm{BB}) \mathrm{Cu}^{\mathrm{II}}\left(\mathrm{H}_{2} \mathrm{O}\right)_{2}\right](\mathrm{OTf})_{2} / \mathrm{H}_{2} \mathrm{O}_{2} / \mathrm{NEt}_{3}$ oxidizes cellobiose both in acetonitrile and aqueous phosphate buffer solutions, as evidenced from product analysis by high-performance liquid chromatography-mass spectrometry. The mixture of $\left[(2 \mathrm{BB}) \mathrm{Cu}^{\mathrm{II}}\left(\mathrm{H}_{2} \mathrm{O}\right)_{2}\right](\mathrm{OTf})_{2} / \mathrm{H}_{2} \mathrm{O}_{2} / \mathrm{NEt}_{3}$ results in more extensive cellobiose degradation. Likewise, the use of both $\left[(\mathbf{2 B B}) \mathrm{Cu}^{\mathrm{I}}\right] \mathrm{OTf}$ and $\left[(\mathbf{2 B B}) \mathrm{Cu}^{\mathrm{II}}\left(\mathrm{H}_{2} \mathrm{O}\right)_{2}\right](\mathrm{OTf})_{2}$ with $\mathrm{KO}_{2}$ afforded cellobiose oxidation products. In all cases, a common $\mathrm{Cu}(\mathrm{II})$ complex formulated as $\left[(\mathbf{2 B B}) \mathrm{Cu}^{\mathrm{II}}(\mathrm{OH})\left(\mathrm{H}_{2} \mathrm{O}\right)\right]^{+}$was detected by mass spectrometry as the final form of the complex.

\section{INTRODUCTION}

The recently reported lytic polysaccharide monooxygenases (LPMOs), ${ }^{1}$ also known as the auxiliary activity (AA) family of copper-dependent enzymes, ${ }^{2}$ feature a conserved type 2 copper binding site with a $\mathrm{N}_{3}$ donor set defined by two imidazoles and a backbone nitrogen from one of the histidine residues, in a structural motif described as the "histidine brace" (Chart 1). ${ }^{2 a, 3}$ These enzymes oxidatively cleave the polymeric chains of recalcitrant polysaccharides to assist hydrolytic enzymes and have potential applications in biomass conversion to renewable biofuels. Recent studies have established some of the aspects that govern substrate binding, such as H-bonding to the primary amine of the histidine brace, ${ }^{4}$ as well as the potential involvement of dioxygen ${ }^{5}$ or hydrogen peroxide ${ }^{6}$ as oxidants. However, details of the mechanism, potential intermediates in the key $\mathrm{C}-\mathrm{H}$ activation step, and subsequent polysaccharide hydroxylation remain to be determined. Although cupricsuperoxo and oxyl complexes have been suggested as the reactive intermediates, a mechanistic insight may be obtained from synthetic models. In this regard, few biomimetic LPMO-

Received: March 21, 2019

Accepted: June 6, 2019

Published: June 20, 2019 
Chart 1. (a) Schematic Representation of the Active Site of LPMO, (b) 2BB, and (c) Mercury Diagram of the Dication $\left[(2 \mathrm{BB}) \mathrm{Cu}^{\mathrm{II}}\left(\mathrm{H}_{2} \mathrm{O}\right)_{2}\right]^{2+15}$

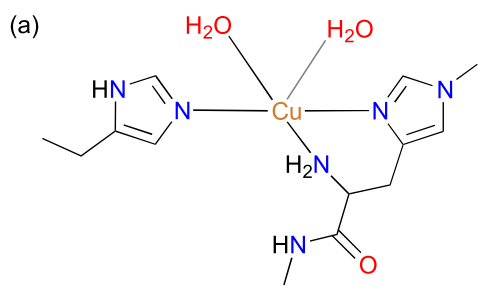

(b)

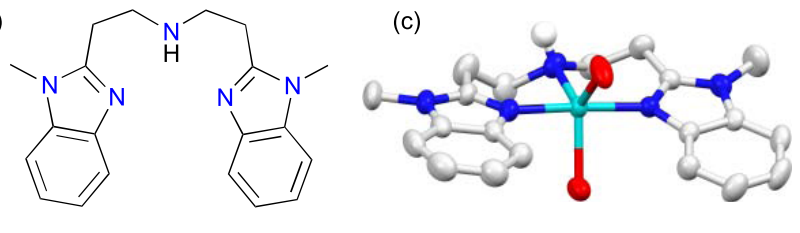

inspired copper complexes have been reported to date, ${ }^{7}$ despite the numerous reports on biologically inspired copperoxygen systems. ${ }^{8}$

Due to the ubiquitous presence of coordinated histidine residues in metalloenzyme active sites, most bioinspired complexes employ amines and nitrogen-containing heterocycles as histidine models. This approach has relied heavily on amine-, pyrazole-, and pyridine-based ligands. In contrast, reports on ligands that incorporate the more electronically relevant imidazolyl and/or benzimidazolyl donor substituents remain relatively scarce, ${ }^{9}$ with the notable exception of the binucleating scaffolds developed by the groups of Casella. ${ }^{10}$ We have recently exploited 2 -substituted benzimidazoles to assemble chelating ligands for mononuclear $\mathrm{Cu}^{\mathrm{II} / \mathrm{I}}$ complexes; these ligands offer versatility as good $\sigma$-donors and reasonable $\pi$-acceptors toward copper ions, as well as varying degrees of steric protection. ${ }^{11}$ Exploration of their reactivity has revealed the formation of free superoxide anions, presumably released by solvent displacement from the putative $\mathrm{Cu}^{\mathrm{II}}$-superoxide species obtained from the corresponding cuprous complexes and $\mathrm{O}_{2}{ }^{11 \mathrm{~d}}$ These steps have been suggested to occur in LPMOs on the basis of DFT calculations ${ }^{5}$ and recently reported structural data, ${ }^{6,12}$ in a rapid inner-sphere reductive activation of $\mathrm{O}_{2}{ }^{5}$

In this context, we recently reported the use of bis[(1methyl-2-benzimidazolyl)ethyl] amine $\left(\mathbf{2 B B},{ }^{13,10 b}\right.$ Chart 1$)$ as a simple structural model of the ligand environment in mononuclear active sites of LPMO. ${ }^{14,15}$ Our interest was spurred by the presence of a methylated nitrogen atom in one of the histidinic imidazoles of fungal $\mathrm{LPMO}^{2 \mathrm{a}}$ and the presence of a central secondary amine available for potential $\mathrm{H}$-bonding with substrates. Additionally, the $2 \mathrm{BB} / \mathrm{Cu}^{\mathrm{II}}$ system afforded complexes with bonding parameters in the range of those of LPMO active sites $(\mathrm{Cu}-\mathrm{N}$ distances of $\sim 1.98 \AA, \mathrm{N}-\mathrm{Cu}-\mathrm{N}$ angles of $\sim 97$ and $\left.\sim 165^{\circ}\right)$. In continuation of these preliminary studies, we herein report detailed spectroscopic studies of $\left[(\mathbf{2 B B}) \mathrm{Cu}^{\mathrm{II} / \mathrm{I}}\right]^{2+/+}$ complexes, their interaction with $\mathrm{O}_{2}, \mathrm{H}_{2} \mathrm{O}_{2}$, and $\mathrm{KO}_{2}$, as well as their oxidative reactivity toward cellobiose as a cellulose model substrate.

\section{RESULTS AND DISCUSSION}

Synthesis of $\mathrm{Cu}^{+}$Complex. Previous attempts to isolate cuprous 2BB complexes required for $\mathrm{O}_{2}$ binding and subsequent reactivity studies were hampered by the low solubility of the tetrafluoroborate or hexafluorophosphate complexes in dichloromethane. ${ }^{13,14}$ However, the use of trifluoromethanesulfonate anions (triflate, OTf) resulted in species soluble in acetonitrile amenable for solution characterization and reactivity studies. Electrospray ionization mass spectrometry (ESI-MS) revealed the presence of a peak at $\mathrm{m} / \mathrm{z}$ 396 assigned to the monomeric $\left[(\mathbf{2 B B}) \mathrm{Cu}^{\mathrm{I}}\right]^{+}$[Figure $\mathrm{S} 1$ in the Supporting Information]. Further characterization by ${ }^{1} \mathrm{H}$ NMR and Fourier transform infrared (FTIR) spectroscopy confirmed the identity of $\left[(\mathbf{2 B B}) \mathrm{Cu}^{\mathrm{I}}\right] \mathrm{OTf}$; its ${ }^{1} \mathrm{H}$ NMR spectrum in $\mathrm{CD}_{3} \mathrm{CN}$ shows relatively broad aromatic signals for the benzimidazole groups at $\delta 7.64,7.24$, and $7.06 \mathrm{ppm}$, the resonance for the $N$-methyl groups was observed at $\delta 3.42$, whereas the methylene protons gave rise to resonances at $\delta$ $3.21\left(-\mathrm{CH}_{2}-\mathrm{N}\right)$ and $3.01 \mathrm{ppm}\left(-\mathrm{CH}_{2}-\mathrm{C}\right)$. FTIR spectroscopy displayed notable bands at $3273(\mathrm{w}) \mathrm{cm}^{-1}$ assigned to the central amine $\mathrm{N}-\mathrm{H}$ stretch, 1027 and 1257 (s) assigned to S$\mathrm{O}$ stretching bands of the triflate anion, as well as a pair of strong bands at 1147 and $1227 \mathrm{~cm}^{-1}$ assigned to $\mathrm{C}-\mathrm{F}$ stretching vibrations; a band at $1614 \mathrm{~cm}^{-1}$ was assigned to the benzimidazole-based $\mathrm{C}=\mathrm{N}$ stretching mode. The main differences with the previously reported cupric complex $\left[(2 \mathrm{BB}) \mathrm{Cu}^{\mathrm{II}}\left(\mathrm{H}_{2} \mathrm{O}\right)_{2}\right](\mathrm{OTf})_{2}$ include the frequencies of the $\mathrm{N}-\mathrm{H}$ stretch at $3241(\mathrm{w}) \mathrm{cm}^{-1}$, the slightly higher intensity of the $\mathrm{C}=\mathrm{N}$ stretching mode previously observed at $1617 \mathrm{~cm}^{-1}$, and the shoulder at $3356 \mathrm{~cm}^{-1}$ that was assigned to $\mathrm{O}-\mathrm{H}$ stretching modes in the cupric complex.

Solid-State Structure of $\left[(2 \mathrm{BB}) \mathrm{Cu}^{\mathrm{l}}\right] \mathrm{OTf}$. $\left[(2 \mathrm{BB}) \mathrm{Cu}^{\mathrm{I}}\right] \mathrm{OTf}$ was dissolved in a minimum amount of anhydrous $\mathrm{CH}_{3} \mathrm{CN}$, and after slow evaporation, colorless $\mathrm{X}$-ray quality crystals of $\left[(2 B B) \mathrm{Cu}^{\mathrm{I}}\right]$ OTf were obtained. The metric parameters around the $\mathrm{Cu}(\mathrm{I})$ center in the $\left[(\mathbf{2 B B}) \mathrm{Cu}^{\mathrm{I}}\right]^{+}$cation are in the range of those reported for the enzymes, displaying the characteristic $\mathrm{T}$ shape of the reduced form of the active sites of LPMOs, as shown in Figure 1 and Tables S1-S3. The N1-Cu1-N4 open

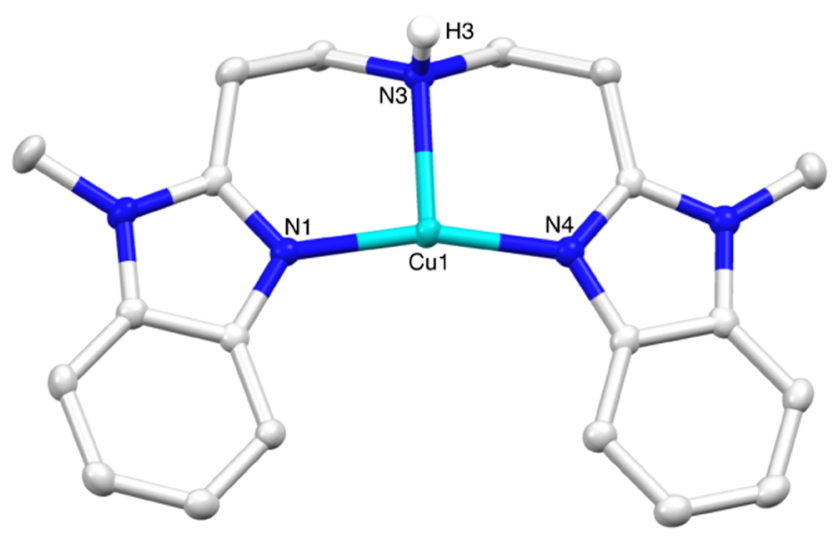

Figure 1. Mercury diagram of $\left[(2 \mathrm{BB}) \mathrm{Cu}^{\mathrm{I}}\right]^{+}$at the $50 \%$ probability level. $\mathrm{H}$ atoms, except for $\mathrm{H} 3$ on the central amine, and the triflate counter ion are omitted for clarity; color code: $\mathrm{C}$, grey; $\mathrm{N}$, blue; $\mathrm{Cu}$, turquoise.

angle of $165^{\circ}$ in $\left[(2 \mathrm{BB}) \mathrm{Cu}^{\mathrm{I}}\right]^{+}$is identical to the corresponding one in the AA9-AA11 active sites, ${ }^{16}$ whereas the two closed angles, $\mathrm{N} 3-\mathrm{Cu} 1-\mathrm{N} 4$ and $\mathrm{N} 1-\mathrm{Cu} 1-\mathrm{N} 3$ of 98.01 and $96.82^{\circ}$, respectively, for $\left[(2 \mathrm{BB}) \mathrm{Cu}^{\mathrm{I}}\right]^{+}$, are equivalent to that of $97^{\circ}$ in LPMO. A comparison of the bond distances is presented in Table 1, showing a larger $\mathrm{Cu}-\mathrm{N}$ distance to the central nitrogen donor than that to the benzimidazole $\mathrm{N}$ atoms. 
Table 1. Bond Distances and Angles in $\left[(2 B B) \mathrm{Cu}^{\mathrm{I}}\right]$ OTf and Comparison with the Corresponding Parameters in Reduced LsAA9A ${ }^{16}$

\begin{tabular}{lclc}
\multicolumn{1}{c}{ parameter } & {$[(2 \mathrm{BB}) \mathrm{Cu}] \mathrm{OTf}$} & \multicolumn{1}{c}{ parameter } & $\mathrm{Cu}(\mathrm{I}) \mathrm{LsAA9A}$ \\
$\mathrm{Cu} 1-\mathrm{N} 4$ & $1.901 \AA$ & $\mathrm{Cu}-\mathrm{N} \sigma(\mathrm{His} 1)$ & $1.9 \AA$ \\
$\mathrm{Cu} 1-\mathrm{N} 1$ & $1.908 \AA$ & $\mathrm{Cu}-\mathrm{N} \varepsilon($ His78) & $2.0 \AA$ \\
$\mathrm{Cu} 1-\mathrm{N} 3$ & $2.173 \AA$ & $\mathrm{Cu}-\mathrm{NH}_{2}(\mathrm{His} 1)$ & $2.2 \AA$ \\
$\mathrm{N} 4-\mathrm{Cu} 1-\mathrm{N} 1$ & $164.54^{\circ}$ & $\mathrm{N} \sigma-\mathrm{Cu}-\mathrm{N} \varepsilon$ & $165^{\circ}$ \\
$\mathrm{N} 4-\mathrm{Cu} 1-\mathrm{N} 3$ & $98.01^{\circ}$ & $\mathrm{N} \sigma-\mathrm{Cu}-\mathrm{NH}_{2}$ & $97^{\circ}$ \\
$\mathrm{N} 1-\mathrm{Cu} 1-\mathrm{N} 3$ & $96.82^{\circ}$ & $\mathrm{N} \varepsilon-\mathrm{Cu}-\mathrm{NH}_{2}$ & $97^{\circ}$
\end{tabular}

Interestingly, the triflate anion interacts with $\left[(2 \mathbf{B B}) \mathrm{Cu}^{\mathrm{I}}\right]^{+}$via hydrogen bonding with the central amine $\mathrm{N}-\mathrm{H}$, defined by an $\mathrm{O} 2 \cdots \mathrm{N} 3$ distance of $3.363(3) \AA$ and an $\mathrm{O} 2 \cdots \mathrm{H} 3-\mathrm{N} 3$ angle of $149(2)^{\circ}$.

Solution Studies of $\left[(2 \mathrm{BB}) \mathrm{Cu}^{\prime \prime}\left(\mathrm{H}_{2} \mathrm{O}\right)_{2}\right](\mathrm{OTf})_{2}$. Insight into the nature of the cupric complex in an aqueous solution was gained through equilibrium studies to determine its speciation. Potentiometric titration of $2 \mathrm{BB}$ afforded $\mathrm{p} K_{\mathrm{a}}$ values of 3.68 , 4.86, and 7.84 for the protonated forms of the two benzimidazolic and amine sites, respectively. The values for the benzimidazolic sites are lower (in water at $25^{\circ} \mathrm{C}$ ) than those of benzimidazole at $5.58,{ }^{17 a} 1$-methylbenzimidazole, 1 ethylbenzimidazole at 4.88, and even 1-methyl-5-chlorobenzimidazole at 3.88. ${ }^{17 \mathrm{~b}}$ Subsequently, the stability constant for $\left[(2 \mathrm{BB}) \mathrm{Cu}^{\mathrm{II}}\left(\mathrm{H}_{2} \mathrm{O}\right)_{2}\right]^{2+}$ was determined at $\log \mathrm{K}=12.44$ after refinement of the potentiometric data with Hyperquad software, ${ }^{18}$ considering temperature, volumes, and concentrations of analytes $\left(\mathrm{HNO}_{3}, \mathrm{NaOH}\right.$, potassium biphthalate, 2BB, and its cupric complex, see Figure $S 2$ ). This $\log K$ value is high compared to that of $\mathrm{Cu}$ (II) with bidentate 2hydroxymethylbenzimidazole and 1-methyl-2-hydroxymethylbenzimidazole at 9.30 and 9.66 , respectively. ${ }^{17 a}$

The species distribution was determined with MEDUSA software $^{19}$ (ionic strength $0.1 \mathrm{M} \mathrm{NaNO}_{3}$ ), where the dicationic species $\left[(\mathbf{2 B B}) \mathrm{Cu}^{\mathrm{II}}\right]^{2+}$ clearly predominates in the $\mathrm{pH}$ range of 4-8; see Figure 2. One or two molecules of water are likely

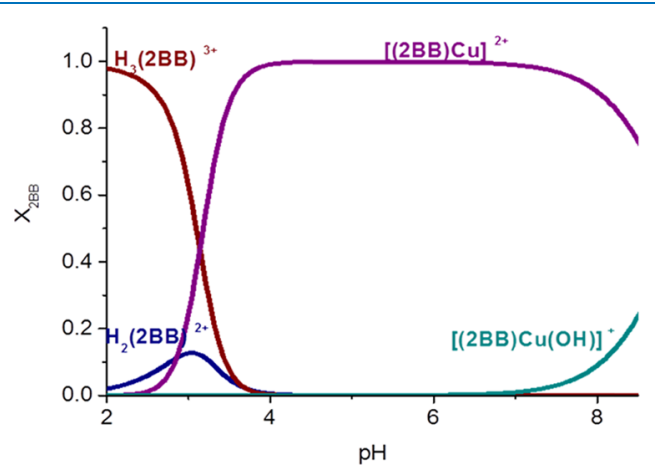

Figure 2. Speciation diagram for $\left[(2 \mathbf{B B}) \mathrm{Cu}^{\mathrm{II}}\right]^{2+}$.

coordinated to the cupric ion in solution to form [(2BB)$\left.\mathrm{Cu}^{\mathrm{II}}\left(\mathrm{H}_{2} \mathrm{O}\right)_{n}\right]^{2+}(n=1,2)$, as observed in the solid state. ${ }^{15}$ Interestingly, a monodeprotonated species is predicted to be present around $\mathrm{pH} 7.5$ and above, which was assigned to a cupric-hydroxo complex $\left[(2 \mathrm{BB}) \mathrm{Cu}^{\mathrm{II}}(\mathrm{OH})\left(\mathrm{H}_{2} \mathrm{O}\right)_{n-1}\right]^{+}$, likely in the form of a bridged dimer $\left[\left\{(2 \mathrm{BB}) \mathrm{Cu}^{\mathrm{II}}\left(\mathrm{H}_{2} \mathrm{O}\right)_{n-1}\right\}_{2}(\mu\right.$ $\left.\mathrm{OH})_{2}\right]^{2+}$, with $\log K=15.88$. This type of species would be favored over a complex with a deprotonated central amine, on the basis of the additional experimental evidence for a hydroxo-bridged dicopper complex (vide infra). Further support for deprotonation of a coordinated water molecule over an amine donor is provided by studies on the effect of metal coordination on the $\mathrm{p} K_{\mathrm{a}}$ values of biologically relevant ligands, with transition-metal ions increasing the acidity by $1-$ $3 \log$ units. $^{20}$ These observations suggest that the potential involvement of a deprotonated amine during the catalytic cycle may be ruled out in our system and plausibly in the active site of LPMO as well. In the enzymatic system, the proposed deprotonation of the terminal amine of the histidine brace ${ }^{12}$ seems unlikely near neutral $\mathrm{pH}^{4-6}$ particularly considering determinations of the $\mathrm{p} K_{\mathrm{a}}$ values of terminal amino groups in related ATCUN peptide complexes. ${ }^{21}$ Quantum refinement of $\mathrm{X}$-ray and neutron diffraction data also argues against $-\mathrm{NH}_{2}$ deprotonation. $^{22}$

Electrochemical Studies. The species distribution is supported by electrochemical results obtained at $\mathrm{pH}$ 5.0, 7.0, 9.0 , and 10.5 of aqueous solutions of $\left[(2 \mathrm{BB}) \mathrm{Cu}^{\mathrm{II}}\left(\mathrm{H}_{2} \mathrm{O}\right)_{2}\right]$ $(\mathrm{OTf})_{2}$. The system behaves quasireversibly, with one redox wave assigned to the $\mathrm{Cu}^{\mathrm{II} / \mathrm{I}}$ couple at $E_{1 / 2}=226 \mathrm{mV}$ vs standard hydrogen electrode (SHE) at $\mathrm{pH}$ 5.0-7.0, which is in the range of the redox potentials reported for LPMOs (150$370 \mathrm{mV}$ vs SHE). Differences were observed at $\mathrm{pH}$ 9.0-10.5; in the former case, a shoulder at a slightly more negative potential indicates the presence of an additional species. This is confirmed at $\mathrm{pH} 10.5$, where the shoulder becomes the only wave observed (Figure 3). In $\mathrm{CH}_{3} \mathrm{CN}$, electrochemical analysis of $\left[(2 \mathrm{BB}) \mathrm{Cu}^{\mathrm{I}}\right]$ OTf shows a quasireversible behavior, with $E_{1 / 2}$ $=76 \mathrm{mV}$ vs SHE $(-272 \mathrm{mV}$ vs ferrocenium $/$ ferrocene, Figure S3).

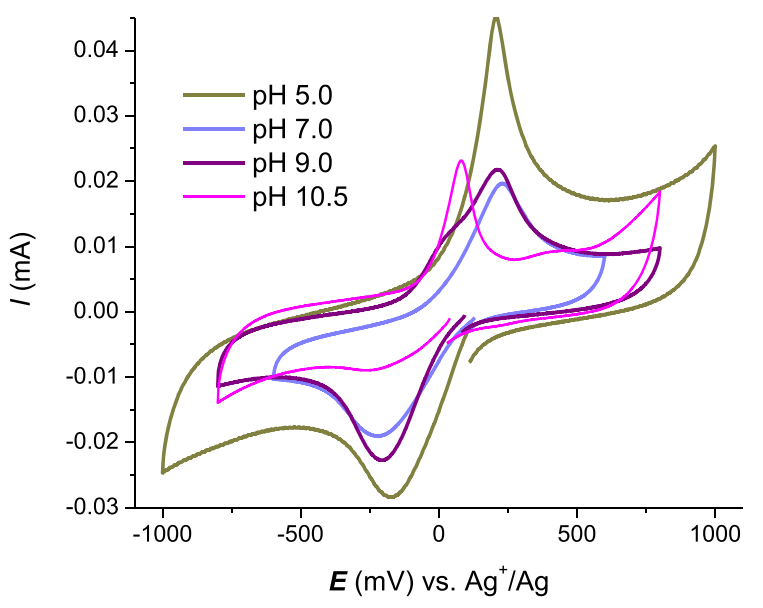

Figure 3. Cyclic voltammograms of $1 \mathrm{mM}\left[(\mathbf{2 B B}) \mathrm{Cu}^{\mathrm{II}}\left(\mathrm{H}_{2} \mathrm{O}\right)_{2}\right]$ $(\mathrm{OTf})_{2}$ solutions in phosphate buffer $(\mathrm{PB})$ at $\mathrm{pH}$ 5.0, 7.0, and 9.0, and in carbonate buffer at $\mathrm{pH} 10.5$, acquired at $1 \mathrm{~V} \mathrm{~s}^{-1}$ with a glassy carbon electrode (at $\mathrm{pH} 10.5$, the system is heterogeneous).

Insight into the identity of the additional species formed at $\mathrm{pH}$ 9.0-10.5 was obtained through ESI-MS analysis of a solution of $\left[(2 \mathrm{BB}) \mathrm{Cu}^{\mathrm{II}}\left(\mathrm{H}_{2} \mathrm{O}\right)_{2}\right](\mathrm{OTf})_{2}$. A signal was detected at $m / z 887$, which was assigned to the mixed hydroxo/ carbonato-bridged dicopper complex shown in Scheme 1 on the basis of its mass and isotope distribution. The complex detected may be formed upon aerobic $\mathrm{CO}_{2}$ insertion into an initially formed dihydroxo-bridged dimeric complex $[\{(2 \mathrm{BB})$ $\left.\left.\mathrm{Cu}^{\mathrm{II}}\left(\mathrm{H}_{2} \mathrm{O}\right)_{x}\right\}_{2}(\mu-\mathrm{OH})_{2}\right]^{2+23} \mathrm{UV}-$ vis spectroscopic evidence of the formation of the putative $\left[\left\{(2 \mathrm{BB}) \mathrm{Cu}^{\mathrm{II}}\left(\mathrm{H}_{2} \mathrm{O}\right)_{x}\right\}_{2}(\mu\right.$ $\left.\mathrm{OH})_{2}\right]^{2+}$ was obtained by addition of $\mathrm{NEt}_{3}$ to an acetonitrile solution of $\left[(2 \mathrm{BB}) \mathrm{Cu}^{\mathrm{II}}\left(\mathrm{H}_{2} \mathrm{O}\right)_{2}\right](\mathrm{OTf})_{2}$ at room temperature. 
Scheme 1. Proposed Hydroxo/Carbonato-Bridged Dicopper Complex Formed from $\left[(2 \mathrm{BB}) \mathrm{Cu}^{\mathrm{II}}\left(\mathrm{H}_{2} \mathrm{O}\right)_{2}\right](\mathrm{OTf})_{2}$ in Water at pH 9.0 with Experimental (Left) and Simulated Isotopic Mass Spectrometry Patterns (Right)

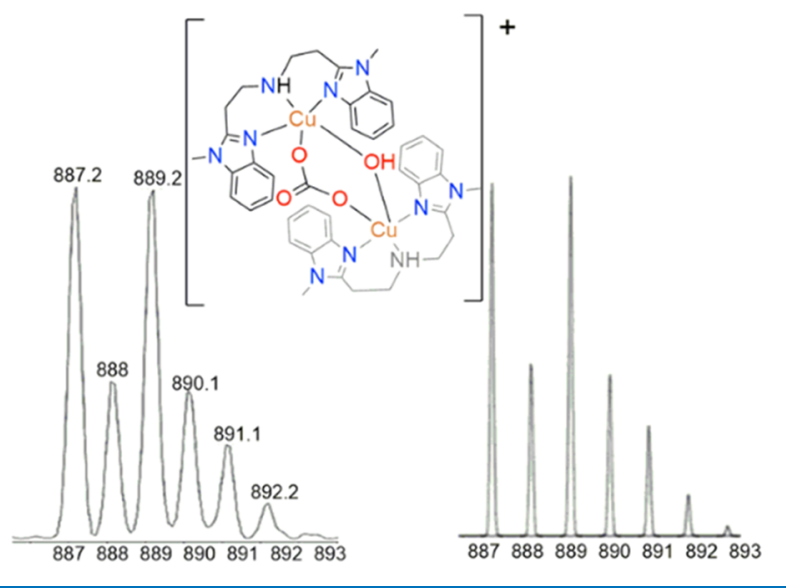

A new band was observed at $330 \mathrm{~nm}\left(\varepsilon \sim 2000 \mathrm{M}^{-1} \mathrm{~cm}^{-1}\right)$, which can be assigned as a hydroxo to $\mathrm{Cu}$ (II) ligand-to-metal charge-transfer (LMCT) transition; see Figure S4.

These observations confirm that deprotonation of a coordinated water molecule is more facile than that of the amine in our system. This deprotonation occurs at a higher $\mathrm{pH}$ value (7.5) than that used in the study suggesting terminal amine deprotonation (i.e., $\mathrm{pH} 7.0),{ }^{12}$ further emphasizing that the amine is likely to remain protonated at enzymatic $\mathrm{pH}$.
Moreover, the optimum $\mathrm{pH}$ value for enzymatic activity is slightly acidic, ${ }^{4,5}$ rendering the deprotonation of the terminal amine even less likely.

Reactivity of $\left[(2 \mathrm{BB}) \mathrm{Cu}^{\prime}\right] \mathrm{OTf}$ with $\mathrm{O}_{2}$. The reactivity of $\left[(\mathbf{2 B B}) \mathrm{Cu}^{\mathrm{I}}\right]$ OTf with dioxygen was explored initially by UVvis spectroscopy at low temperature in an acetonitrile solution. Gentle bubbling of $\mathrm{O}_{2}$ through $0.3 \mathrm{mM}$ solutions of $\left[(2 \mathrm{BB}) \mathrm{Cu}^{\mathrm{I}}\right] \mathrm{OTf}$ at $243 \mathrm{~K}$ resulted in the appearance of a broad band at $360 \mathrm{~nm}$, assigned to ligand-to-metal charge transfer (LMCT) of a copper-oxygen species, accompanied by $\mathrm{d}-\mathrm{d}$ transition at $680 \mathrm{~nm}$; a similar behavior was observed in acetone at $193 \mathrm{~K}$. The species was stable for at least an hour, although decay was observed when the temperature was raised; see Figure S5. These changes were not observed under similar conditions or at lower temperature in tetrahydrofuran (THF) solutions, and reactivity studies in this solvent were not pursued. In aqueous phosphate buffer (PB) at $273 \mathrm{~K}$, no significant changes were observed by UV-vis spectroscopy upon bubbling $\mathrm{O}_{2}$ through in situ-reduced (with $1.2-1.5$ equiv of sodium ascorbate) $\left[(2 \mathrm{BB}) \mathrm{Cu}^{\mathrm{II}}\left(\mathrm{H}_{2} \mathrm{O}\right)_{2}\right](\mathrm{OTf})_{2}$. In both acetonitrile and $\mathrm{PB}$ solutions, the products generated at low temperature were characterized by ESI-MS, revealing the presence of an intense signal at $\mathrm{m} / z 396$ assigned to $\left[(2 \mathrm{BB}) \mathrm{Cu}^{\mathrm{I}}\right]^{+}$; see Figure S1.

The mixture was characterized by electron paramagnetic resonance (EPR) spectroscopy, revealing that although $\left[(2 B B) \mathrm{Cu}^{\mathrm{I}}\right]$ OTf reacts slowly with dioxygen in acetonitrile at $243 \mathrm{~K}$, a signal characteristic of a cupric complex in an axial coordination environment appears after ca. $10 \mathrm{~min}\left[g_{\|}=2.250\right.$,

Scheme 2. Proposed Reaction Manifolds and Putative Copper Complexes Generated from $\left[(2 \mathrm{BB}) \mathrm{Cu}^{\mathrm{I}}\right]^{+} / \mathrm{O}_{2}(\mathrm{Top} \mathrm{Left})$ or $\left[(2 \mathrm{BB}) \mathrm{Cu}^{\mathrm{II}}(\mathrm{S})_{2}\right]^{2+} / \mathrm{H}_{2} \mathrm{O}_{2} / \mathrm{NEt}_{3}$ (Top Right)
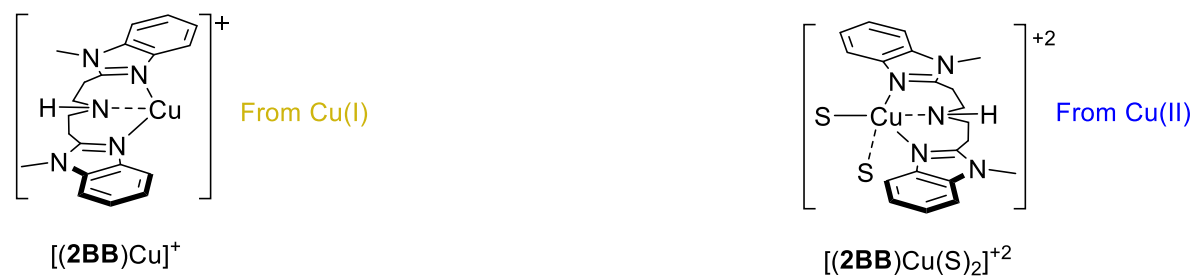

$\left[(2 \mathrm{BB}) \mathrm{Cu}(\mathrm{S})_{2}\right]^{+2}$
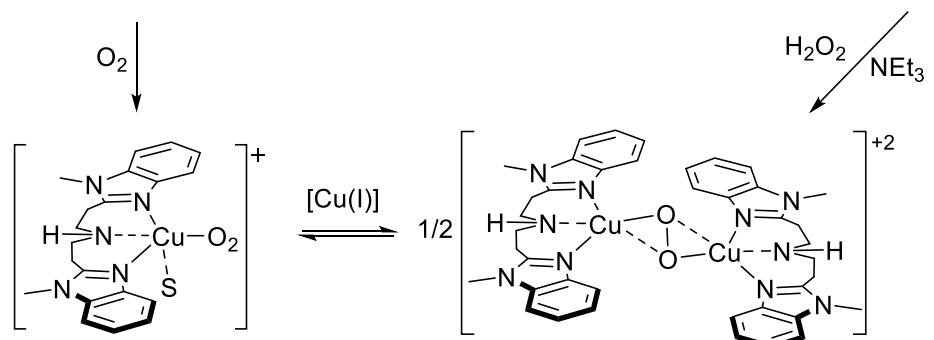

$\left[(2 \mathrm{BB}) \mathrm{Cu}\left(\mathrm{O}_{2}\right)(\mathrm{S})\right]^{+}$

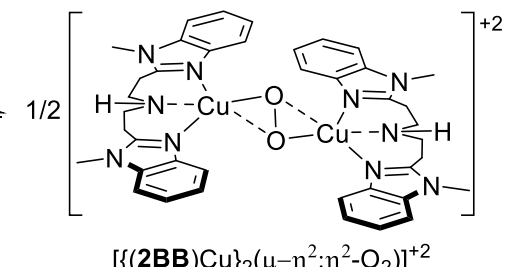

$\left[\{(2 B B) C u\}_{2}\left(\mu-\eta^{2}: \eta^{2}-\mathrm{O}_{2}\right)\right]^{+2}$

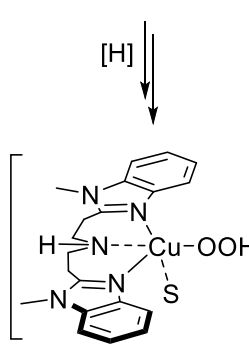

$[(2 \mathrm{BB}) \mathrm{Cu}(\mathrm{OOH})(\mathrm{S})]^{+}$

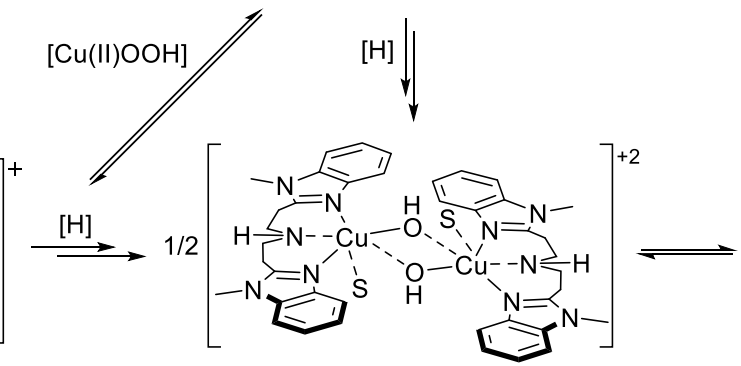

$\left[\{(\mathbf{B B}) \mathrm{Cu}(\mathrm{S})\}_{2}(\mu-\mathrm{OH})_{2}\right]^{+2}$

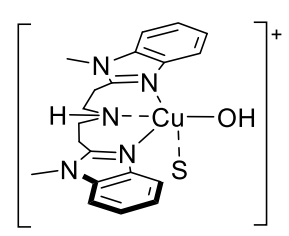

$[(2 \mathrm{BB}) \mathrm{Cu}(\mathrm{OH})(\mathrm{S})]^{+}$ 
$g_{\perp}=2.082, \mathrm{~A}_{\|}=423 \mathrm{MHz}(151 \mathrm{G})$, integration $21 \%$ relative to $\mathrm{Cu}$ (II) external standard]. A reasonable explanation would imply initial formation of an EPR silent cupric-superoxo complex $\left[(2 \mathrm{BB}) \mathrm{Cu}^{\mathrm{II}}\left(\mathrm{O}_{2}\right)\right]^{+}$, likely in equilibrium with a sideon peroxo-bridged dicopper(II) complex $\left[\left\{(\mathbf{2 B B}) \mathrm{Cu}^{\mathrm{II}}\right\}_{2}(\mu\right.$ $\left.\left.\eta^{2}: \eta^{2}-\mathrm{O}_{2}\right)\right]^{2+}$ (on the basis of $\mathrm{UV}-$ vis spectroscopy and $\mathrm{H}_{2} \mathrm{O}_{2}$ reactivity section below). $\mathrm{H}$-abstraction from solvent or cellobiose may result in the EPR-active cupric hydroperoxo $\left[(2 \mathrm{BB}) \mathrm{Cu}^{\mathrm{II}}(\mathrm{OOH})(\mathrm{S})\right]^{+}$and/or the further downstream hydroxo complex $\left[(2 \mathrm{BB}) \mathrm{Cu}^{\mathrm{II}}(\mathrm{OH})(\mathrm{S})\right]^{+}\left(\mathrm{S}=\mathrm{H}_{2} \mathrm{O}\right.$, $\left.\mathrm{CH}_{3} \mathrm{CN}\right)$. These species may give rise to the shoulder at 330 $\mathrm{nm}$ by $\mathrm{UV}-$ vis absorption spectroscopy (Figure S5). $\mathrm{Cu}(\mathrm{I}$ ) oxygenation leading to a $\mathrm{Cu}(\mathrm{II})$-hydroperoxo complex through $\mathrm{H}$-abstraction has been previously observed. ${ }^{24}$ Finally, both $\mathrm{Cu}$ (II)-hydroperoxo and dicopper(II)-peroxo may further react to generate the final product $\left[(2 \mathbf{B B}) \mathrm{Cu}^{\mathrm{II}}(\mathrm{OH})(\mathrm{S})\right]^{+}$, in equilibrium with the dimeric form $\left[\left\{(\mathbf{2 B B}) \mathrm{Cu}^{\mathrm{II}}(\mathrm{S})_{x}\right\}_{2}(\mu\right.$ $\left.\mathrm{OH})_{2}\right]^{2+}$ (Scheme 2).

In $\mathrm{PB} /$ glycerol at $\mathrm{pH} 7.0$ and $273 \mathrm{~K},\left[(2 \mathrm{BB}) \mathrm{Cu}^{\mathrm{II}}\left(\mathrm{H}_{2} \mathrm{O}\right)_{2}\right]$ $(\mathrm{OTf})_{2}$ reduced in situ with 1.2 equiv of sodium ascorbate produced no changes after bubbling of $\mathrm{O}_{2}$, changes were not observed. However, addition of cellobiose to the oxygenated PB solution resulted in an axial signal with $g_{\|}=2.275$ and $g_{\perp}=$ 2.054 and $A_{\|}=502 \mathrm{MHz}(179 \mathrm{G})$ and $A_{\perp}=70 \mathrm{MHz}(25 \mathrm{G})$; see Figure 4; the spectrum was simulated as containing one or

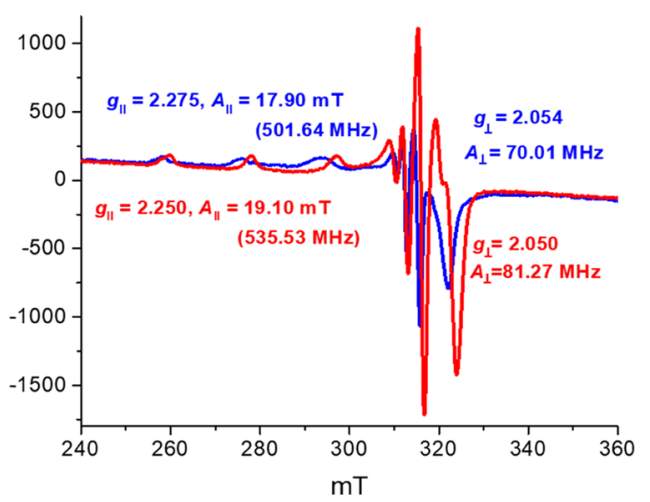

Figure 4. EPR spectra of in situ-generated $\left[(2 \mathrm{BB}) \mathrm{Cu}^{\mathrm{I}}\right]^{+}$with 1.5 equiv of sodium ascorbate after bubbling $\mathrm{O}_{2}$ and adding 10 equiv of cellobiose ( $3 \mathrm{mM}$ in $\mathrm{PB}$, blue trace), and mixture of $\left[(\mathbf{2 B B}) \mathrm{Cu}^{\mathrm{I}}\right] \mathrm{OTf}$, 1.2 equiv of $\mathrm{KO}_{2}$, and 10 equiv of cellobiose $\left(3 \mathrm{mM}\right.$ in $\mathrm{CH}_{3} \mathrm{CN}$, red trace).

two $\mathrm{Cu}$ (II) species, with only the former case resulting in a good fit. Examples of mononuclear copper-hydroperoxo complexes featuring tripodal pyridylamine and pyridylaminethioether ligands have been characterized by EPR spectroscopy and assigned to trigonal bipyramidal $\left[g_{\|}=2.004, g_{\perp}=2.207\right.$, $\left.A_{\|}=\mathrm{MHz} 305(109 \mathrm{G}), A_{\perp}=210 \mathrm{MHz}(75 \mathrm{G})\right]^{25}$ or square pyramidal geometries $\left[g_{\|}=2.24, g_{\perp}=2.06, A_{\|}=471 \mathrm{MHz}\right.$ $\left.(168 \mathrm{G}) ; g_{\|}=2.25, g_{\perp}=2.04, A_{\|}=504 \mathrm{MHz}(180 \mathrm{G})\right] .{ }^{26} \mathrm{~A}$ similar situation has been observed with monomeric cuprichydroxo complexes: EPR spectroscopic data for tripodal complexes have been observed to give rise to "inverse" signals, whereas axial signals with some degree of rhombicity have been observed in the few cases of tetragonal $\mathrm{Cu}(\mathrm{II})-\mathrm{OH}$ complexes $\left[g_{x}=2.032, g_{y}=2.055, g_{z}=2.185, A_{\mathrm{Cu}}=588 \mathrm{MHz}\right.$ $\left.(189 \mathrm{G}), A_{\mathrm{N}}=40-53 \mathrm{MHz}(14-19 \mathrm{G})\right] .^{27}$ Resemblance of the parameters to those of the tetragonal species suggests a square pyramidal coordination environment for the putative $\mathrm{Cu}$ (II)-hydroperoxo ${ }^{7,26}$ or hydroxo complexes, likely with weak donors in the axial positions $\left[(2 \mathrm{BB}) \mathrm{Cu}^{\mathrm{II}}(\mathrm{OOH})(\mathrm{S})\right]^{+}$or $\left[(\mathbf{2 B B}) \mathrm{Cu}^{\mathrm{II}}(\mathrm{OH})(\mathrm{S})\right]^{+}(\mathrm{S}=$ solvent, see Scheme 2$)$.

Reactivity of $\left[(2 \mathrm{BB}) \mathrm{Cu}^{\prime}\right] \mathrm{OTf}$ and $\left[(2 \mathrm{BB}) \mathrm{Cu}^{\prime \prime}\left(\mathrm{H}_{2} \mathrm{O}\right)_{2}\right]-$ $(\mathrm{OTf})_{2}$ with $\mathrm{KO}_{2}$. The reactivity of the copper complexes with a one-electron reduced form of dioxygen was explored with $\mathrm{KO}_{2}$; this may be important to establish the oxidant in LPMOs, since $\mathrm{H}_{2} \mathrm{O}_{2}$ has been suggested instead of the originally proposed $\mathrm{O}_{2}{ }^{6}$. Thus, addition of $\mathrm{KO}_{2}$ to solutions of $\left[(2 \mathrm{BB}) \mathrm{Cu}^{\mathrm{I}}\right]$ OTf was monitored by UV-vis absorption spectroscopy to identify potential copper-oxygen species, both in acetonitrile and $\mathrm{PB}$ solution at $\mathrm{pH}$ 7.0. In acetonitrile, the main spectral change consisted of a shoulder at $365 \mathrm{~nm}$, which intensified slightly after addition of cellobiose. Analysis of the reaction mixture by ESI-MS revealed the presence of a peak at $m / z 431$ assigned to $\left[(2 \mathrm{BB}) \mathrm{Cu}^{\mathrm{II}}(\mathrm{OH})\left(\mathrm{H}_{2} \mathrm{O}\right)\right]^{+}$, along with peaks at $\mathrm{m} / z 396$ and 545 characteristic of $\left[(2 \mathrm{BB}) \mathrm{Cu}^{\mathrm{I}}\right]^{+}$ and $\left[(2 \mathrm{BB}) \mathrm{Cu}^{\mathrm{II}}(\mathrm{OTf})\right]^{+}$(Figure S6). When cellobiose was added, ESI-MS evidenced the presence of oxidative degradation products (vide infra). An analogous behavior was observed in PB by UV-vis, although the shoulder was observed at $345 \mathrm{~nm}$. Three relevant peaks were detected by ESI-MS: the one at $m / z 412$ is consistent with a monooxygenation product $\left[(\mathbf{2 B B}) \mathrm{Cu}^{\mathrm{II}}(\mathrm{O})\right]^{+}$, which could correspond to ligand hydroxylation, although such a product was not detected after demetallation with excess aqueous ammonia; a cupryl species cannot be firmly supported without further evidence. A peak at $\mathrm{m} / z 428$ was assigned to the putative cupric-superoxo $\left[(2 \mathrm{BB}) \mathrm{Cu}^{\mathrm{II}}\left(\mathrm{O}_{2}\right)\right]^{+}$and the one at $m / z 602$ was tentatively assigned to $\left[(2 \mathrm{BB}) \mathrm{Cu}^{\mathrm{II}}(\mathrm{O})(\mathrm{OTf})-\right.$ $\left.\left(\mathrm{CH}_{3} \mathrm{CN}\right)\right]^{+}$(Figure $\mathrm{S} 7$ ); the aforementioned species at $\mathrm{m} / z$ 396 and 545 were also detected. These observations imply that highly reactive copper-oxygen species are formed in the $\mathrm{Cu}(\mathrm{I}) / \mathrm{KO}_{2}$ system, allowing detection of the relatively stable downstream product $\left[(2 \mathrm{BB}) \mathrm{Cu}^{\mathrm{II}}(\mathrm{OH})\left(\mathrm{H}_{2} \mathrm{O}\right)\right]^{+}$.

EPR spectra recorded from flash frozen samples over the course of the reaction reveal that after addition of $\mathrm{KO}_{2}$ to $\left[(\mathbf{2 B B}) \mathrm{Cu}^{\mathrm{I}}\right]$ OTf in acetonitrile, a signal characteristic of a cupric complex in an axial environment appears, with $g_{\|}=$ 2.250 and $g_{\perp}=2.050$ and $A_{\|}=536 \mathrm{MHz}(191 \mathrm{G})$ and $A_{\perp}=81$ $\mathrm{MHz}(29 \mathrm{G})$, Figure 4. The signal becomes more intense upon addition of cellobiose, possibly due to generation of the proposed $\left[(2 \mathrm{BB}) \mathrm{Cu}^{\mathrm{II}}(\mathrm{OH})\left(\mathrm{H}_{2} \mathrm{O}\right)\right]^{+}$after $\mathrm{H}$-abstraction, ${ }^{27}$ which was detected by ESI-MS. The analogous reaction of $\left[(2 \mathrm{BB}) \mathrm{Cu}^{\mathrm{II}}\left(\mathrm{H}_{2} \mathrm{O}\right)_{2}\right](\mathrm{OTf})_{2}$ in either $\mathrm{CH}_{3} \mathrm{CN}$ or PB solutions with $\mathrm{KO}_{2}$ did not show considerable changes in its UV-vis absorption spectra, even after addition of cellobiose. No evidence for copper-oxygen species was obtained by ESI-MS or EPR spectroscopy in the reactions of the $\mathrm{Cu}$ (II) complex with $\mathrm{KO}_{2}$. Thus, a cupric-superoxo complex cannot be detected under these conditions.

Reactivity of [(2BB)Cu]OTf and [(2BB)Cu" $\left.\left(\mathrm{H}_{2} \mathrm{O}\right)_{2}\right](\mathrm{OTf})_{2}$ with $\mathrm{H}_{2} \mathrm{O}_{2}$. The reaction of $\left[(2 \mathrm{BB}) \mathrm{Cu}^{\mathrm{II}}\left(\mathrm{H}_{2} \mathrm{O}\right)_{2}\right](\mathrm{OTf})_{2}$ with $\mathrm{H}_{2} \mathrm{O}_{2}$ was monitored by UV-vis spectroscopy to determine whether different species are formed relative to the reaction of the $\mathrm{Cu}(\mathrm{I})$ complex with $\mathrm{O}_{2}$, both in acetonitrile and $\mathrm{PB}(\mathrm{pH}$ 7.0). In acetonitrile, no changes with respect to the original spectrum were observed, even after addition of cellobiose; an analogous behavior was observed in PB. High-performance liquid chromatography-mass spectrometry (HPLC-MS) analysis indicated that cellobiose did not undergo degradation. In contrast, reaction of $\left[(2 \mathrm{BB}) \mathrm{Cu}^{\mathrm{II}}\left(\mathrm{H}_{2} \mathrm{O}\right)_{2}\right](\mathrm{OTf})_{2}$ with $1: 1$ mixtures of $\mathrm{H}_{2} \mathrm{O}_{2} / \mathrm{Et}_{3} \mathrm{~N}$ in acetonitrile resulted in spectral changes characterized mainly by an absorbance maximum 
around $365 \mathrm{~nm}$ (see Figures S8 and S9) and a d-d transition at $670 \mathrm{~nm}$. Another copper complex appears to be present, on the basis of the shoulder observed at ca. $330 \mathrm{~nm}$. A mixture of the proposed dimeric $\left[\left\{(2 \mathrm{BB}) \mathrm{Cu}^{\mathrm{II}}\right\}_{2}\left(\mu-\eta^{2}: \eta^{2}-\mathrm{O}_{2}\right)\right]^{2+}$ and monomeric $\left[(2 \mathbf{B B}) \mathrm{Cu}^{\mathrm{II}}(\mathrm{OOH})(\mathrm{S})\right]^{+}$and /or $[(\mathbf{2 B B})-$ $\left.\mathrm{Cu}^{\mathrm{II}}(\mathrm{OH})(\mathrm{S})\right]^{+}$complexes (cf. Scheme 2 ) may be responsible for the optical features described, with ample precedent for $\mu$ $\eta^{2}: \eta^{2}$-peroxo dicopper(II) complexes with intense absorption bands around $360 \mathrm{~nm} \cdot{ }^{10,28}$ The few examples reported of monomeric, tetragonal cupric hydroperoxo, and hydroxo complexes feature LMCT bands that are blue-shifted relative to the dimeric peroxo-bridged species, ${ }^{25-27}$ which is consistent with our observations. The similarity with the UV-vis absorption spectrum of the reaction mixture with $\left[(2 B B) \mathrm{Cu}^{\mathrm{I}}\right]^{+}$ and dioxygen (see Figure S10) further suggests the formation of peroxo dicopper(II) species in the reaction of $\mathrm{Cu}(\mathrm{I})$ with $\mathrm{O}_{2}$ described above. $\left[\left\{(\mathbf{2 B B}) \mathrm{Cu}^{\mathrm{II}}\right\}_{2}\left(\mu-\eta^{2}: \eta^{2}-\mathrm{O}_{2}\right)\right]^{2+}$ may form by rapid capture of an initially formed cupric-superoxo [(2BB)$\left.\mathrm{Cu}^{\mathrm{II}}\left(\mathrm{O}_{2}\right)\right]^{+}$by a second equivalent of $\left[(2 \mathrm{BB}) \mathrm{Cu}^{\mathrm{I}}\right]^{+}$. The reaction of $\left[(2 \mathrm{BB}) \mathrm{Cu}^{\mathrm{I}}\right]$ OTf with $\mathrm{H}_{2} \mathrm{O}_{2}$ was also analyzed by $\mathrm{UV}$-vis absorption and EPR techniques, resulting in spectra with poorly defined features.

The presence of dicopper species in acetonitrile solution was confirmed by cryospray ionization mass spectrometry (CSIMS) under conditions that are similar to those employed for $\mathrm{UV}-$ vis absorption spectroscopy. As soon as 3 equiv of $\mathrm{H}_{2} \mathrm{O}_{2}$ / $\mathrm{Et}_{3} \mathrm{~N}$ were added to $\left[(2 \mathrm{BB}) \mathrm{Cu}^{\mathrm{II}}\left(\mathrm{H}_{2} \mathrm{O}\right)_{2}\right](\mathrm{OTf})_{2}$ in acetonitrile, the sample was injected at $243 \mathrm{~K}$, identifying $\left[(2 \mathrm{BB}){ }_{2} \mathrm{Cu}_{2}{ }^{\mathrm{II}}\left(\mu-\mathrm{CO}_{3}\right)(\mathrm{OTf})\right]^{+}, \quad\left[(\mathbf{2 B B})_{2} \mathrm{Cu}_{2}{ }^{\mathrm{II}}\left(\mu-\mathrm{O}_{2}\right)\right]^{2+}$, and $\left[(2 \mathrm{BB}) \mathrm{Cu}^{\mathrm{II}}(\mathrm{OH})\left(\mathrm{H}_{2} \mathrm{O}\right)\right]^{+}$. Spectral comparison with the injected sample acquired at $293 \mathrm{~K}$ (once the band at 365 $\mathrm{nm}$ decayed) shows that similar species are formed, but the bimetallic species are favored at higher temperature, on the basis of their intensities (Table S4 and Figure S11).

Analysis of the reaction mixture by EPR spectroscopy reveals that after reaction of $\left[(2 \mathrm{BB}) \mathrm{Cu}^{\mathrm{II}}\left(\mathrm{H}_{2} \mathrm{O}\right)_{2}\right](\mathrm{OTf})_{2}$ with $1: 1$ $\mathrm{H}_{2} \mathrm{O}_{2} / \mathrm{Et}_{3} \mathrm{~N}$ in acetonitrile, the signal characteristic of a cupric complex in an axial coordination environment becomes weak after ca. $10 \mathrm{~min}$, likely due to formation of the antiferromagnetically coupled $\left[\left\{(2 \mathrm{BB}) \mathrm{Cu}^{\mathrm{II}}\right\}_{2}\left(\mu-\eta^{2}: \eta^{2}-\mathrm{O}_{2}\right)\right]^{2+}$; this species is stable for at least $2 \mathrm{~h}$ at $243 \mathrm{~K}$, on the basis of UV-vis and EPR measurements.

Addition of the potentially chelating acetate anion $\left(\mathrm{OAc}^{-}, 3\right.$ equiv in methanol/acetonitrile) to $0.3 \mathrm{mM} \mathrm{[(2BB)-}$ $\left.\mathrm{Cu}^{\mathrm{II}}\left(\mathrm{H}_{2} \mathrm{O}\right)_{2}\right](\mathrm{OTf})_{2}$ in acetonitrile was tested to interrogate the nature of the dimeric species formed upon addition of 30 equiv of $\mathrm{H}_{2} \mathrm{O}_{2} / \mathrm{Et}_{3} \mathrm{~N} .^{29,30}$ The reaction was monitored by UVvis absorption spectroscopy at $243 \mathrm{~K}$, showing the generation of the band at $365 \mathrm{~nm}$, attributed to $\left[\left\{(2 \mathrm{BB}) \mathrm{Cu}^{\mathrm{II}}\right\}_{2}\left(\mu-\eta^{2}: \eta^{2}\right.\right.$ $\left.\left.\mathrm{O}_{2}\right)\right]^{2+}$, along with new bands at 414 and $440 \mathrm{~nm}$; see Figure 5.

The band at $365 \mathrm{~nm}$ decays over a period of $75 \mathrm{~min}$ at 243 $\mathrm{K}$, with concomitant increase in the intensity of the bands at 414 and $440 \mathrm{~nm}$; this transformation occurs almost instantaneously by increasing the temperature to $293 \mathrm{~K}$. Similar results were observed upon addition of $\mathrm{O}_{2}, \mathrm{KO}_{2}$, or $\mathrm{H}_{2} \mathrm{O}_{2}$ to cuprous and cupric complexes in the presence of $\mathrm{OAc}^{-}$. CSI-MS analysis of the final products at $243 \mathrm{~K}$ revealed the presence of $\left[(\mathbf{2 B B})_{2} \mathrm{Cu}_{2}{ }^{\mathrm{II}}\left(\mu-\eta^{2}-\mathrm{OAc}\right)_{2}(\mathrm{OTf})\right]^{+}$and $\left[\left\{(\mathbf{2 B B}) \mathrm{Cu}^{\mathrm{II}}\right\}_{2}\left(\mu-\eta^{2}: \eta^{2}-\mathrm{O}_{2}\right)\right]^{2+}$ (Table S5), with their intensities increasing upon warming up the mixture to $293 \mathrm{~K}$; see Figure S12. EPR spectroscopy reveals that once $\mathrm{H}_{2} \mathrm{O}_{2} / \mathrm{Et}_{3} \mathrm{~N}$ is added, the signal characteristic of the cupric complex in an axial coordination environment becomes weak after ca. $10 \mathrm{~min}$

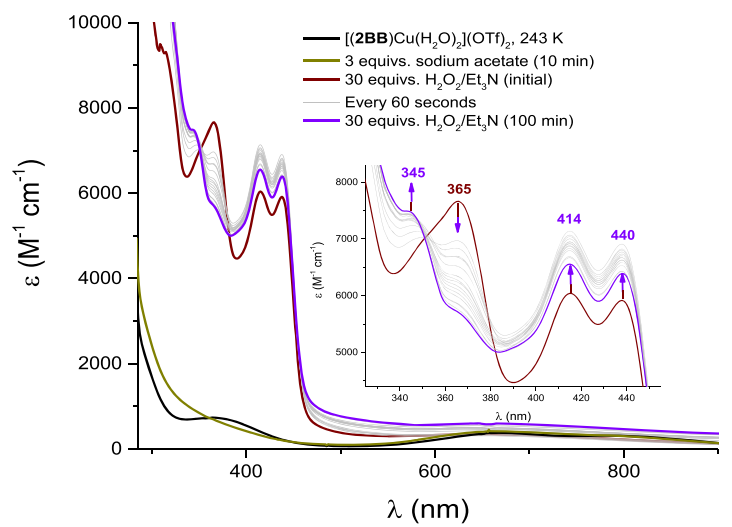

Figure 5. UV-vis absorption spectrum of $\left[(2 \mathbf{B B}) \mathrm{Cu}^{\mathrm{II}}\left(\mathrm{H}_{2} \mathrm{O}\right)_{2}\right]$ (OTf $)_{2}\left(0.3 \mathrm{mM}\right.$ in $\mathrm{CH}_{3} \mathrm{CN}, 3$ equiv of $\mathrm{NaOAc}$ in $60 \mu \mathrm{L}$ of $\mathrm{CH}_{3} \mathrm{CN} /$ $\mathrm{MeOH}$, black trace) after addition of 3 equiv of $1: 1 \mathrm{H}_{2} \mathrm{O}_{2} / \mathrm{Et}_{3} \mathrm{~N}$ (green), and 30 equiv of the same (brown); follow-up of the reaction and the final spectrum after $100 \mathrm{~min}$ (purple trace).

due to formation of the antiferromagnetically coupled $\left[\left\{(\text { 2BB }) \mathrm{Cu}^{\mathrm{II}}\right\}_{2}\left(\mu-\eta^{2}: \eta^{2}-\mathrm{O}_{2}\right)\right]^{2+}$ (Figure S13).

Resonance Raman Spectroscopy. Further characterization of the proposed dimer $\left[\left\{(\mathbf{2 B B}) \mathrm{Cu}^{\mathrm{II}}\right\}_{2}\left(\mu-\eta^{2}: \eta^{2}-\mathrm{O}_{2}\right)\right]^{2+}$ and the associated complex formed upon addition of $\mathrm{NaOAc}$ was attempted by resonance Raman spectroscopy. Since these species give rise to the bands observed by UV-vis absorption spectroscopy at $365 \mathrm{~nm}$ and 414 and $440 \mathrm{~nm}$, respectively, measurements were carried out with mixtures of [(2BB)$\left.\mathrm{Cu}^{\mathrm{II}}\left(\mathrm{H}_{2} \mathrm{O}\right)_{2}\right](\mathrm{OTf})_{2}$ and $1: 1 \mathrm{H}_{2} \mathrm{O}_{2} / \mathrm{Et}_{3} \mathrm{~N}$, with and without added sodium acetate, and excitation at 355 and $457 \mathrm{~nm}$. Raman spectra recorded with excitation at $355 \mathrm{~nm}$ was employed at $243 \mathrm{~K}$ to favor detection of $\left[\left\{(2 \mathrm{BB}) \mathrm{Cu}^{\mathrm{II}}\right\}_{2}(\mu\right.$ $\left.\left.\eta^{2}: \eta^{2}-\mathrm{O}_{2}\right)\right]^{2+}$, whereas excitation at $457 \mathrm{~nm}$ was employed at $293 \mathrm{~K}$ to favor detection of the unidentified species that gives absorption maxima at 414 and $440 \mathrm{~nm}$ (Figures S14 and S15). Although strong signals are present, no isotope-sensitive bands are clearly discernible $\left(\mathrm{H}_{2}{ }^{16} \mathrm{O}_{2}\right.$ vs $\left.\mathrm{H}_{2}{ }^{18} \mathrm{O}_{2}\right)$, as the spectra appear to be dominated by ligand-based vibrations. In the case of $\left[\left\{(2 \mathrm{BB}) \mathrm{Cu}^{\mathrm{II}}\right\}_{2}\left(\mu-\eta^{2}: \eta^{2}-\mathrm{O}_{2}\right)\right]^{2+}$, the main absorption band in the UV-vis spectrum is associated to a $2 \mathrm{BB}$-based transition (see the theoretical section and Figures S21 and S22).

Preparative Scale Oxidations of Cellobiose with $[(2 \mathrm{BB}) \mathrm{Cu}] \mathrm{OTf}$ and $\left[(2 \mathrm{BB}) \mathrm{Cu}\left(\mathrm{H}_{2} \mathrm{O}\right)_{2}\right](\mathrm{OTf})_{2}$. Oxidations of cellobiose using $0.3 \mathrm{mM}$ acetonitrile solutions of [(2BB)$\left.\mathrm{Cu}^{\mathrm{II}}\left(\mathrm{H}_{2} \mathrm{O}\right)_{2}\right](\mathrm{OTf})_{2}, 10$ equiv of $\mathrm{H}_{2} \mathrm{O}_{2} / \mathrm{Et}_{3} \mathrm{~N}$, and 10 equiv of cellobiose at $243 \mathrm{~K}$ were undertaken (cf. Figure S16 and Table S6). Similarly, a comparative reaction was performed by generating the $\mathrm{Cu}(\mathrm{I})$ complex in situ from the reduction of $\left[(2 \mathrm{BB}) \mathrm{Cu}^{\mathrm{II}}\left(\mathrm{H}_{2} \mathrm{O}\right)_{2}\right](\mathrm{OTf})_{2}$ with 10 equiv of sodium ascorbate and subsequent bubbling of $\mathrm{O}_{2}$, followed by addition of 10 equiv of cellobiose (Figure S17 and Table S7). As a common product of these reactions, sodium gluconate was detected by HPLC-MS (Scheme 3 and Table 2), demonstrating that the $\left[(2 \mathrm{BB}) \mathrm{Cu}^{\mathrm{II} / \mathrm{I}}\right]^{2+/+}$ system has biomimetic activity for oxidative cellobiose degradation in the presence of the appropriate oxidizing agent. It should be noted that the reaction that employed in situ-generated $\left[(\mathbf{2 B B}) \mathrm{Cu}^{\mathrm{I}}\right]^{+}$in $\mathrm{PB}$ with $\mathrm{O}_{2}$ as oxidant is slightly more selective toward gluconate formation, since it was detected in higher yield by HPLC-MS. In PB with $\mathrm{H}_{2} \mathrm{O}_{2} / \mathrm{Et}_{3} \mathrm{~N}$ as oxidant, the doubly oxidized glucose in Scheme 3 is the main product (Figure S18). The $\mathrm{H}_{2} \mathrm{O}_{2}$ reaction shows a greater degree of cellobiose degradation, but more products 
Scheme 3. Cellobiose Degradation by $\left[(2 B B) \mathrm{Cu}^{\mathrm{II} / \mathrm{I}}\right]^{2+/+}$ and Several Oxidants, with Main Products Detected by HPLCMS
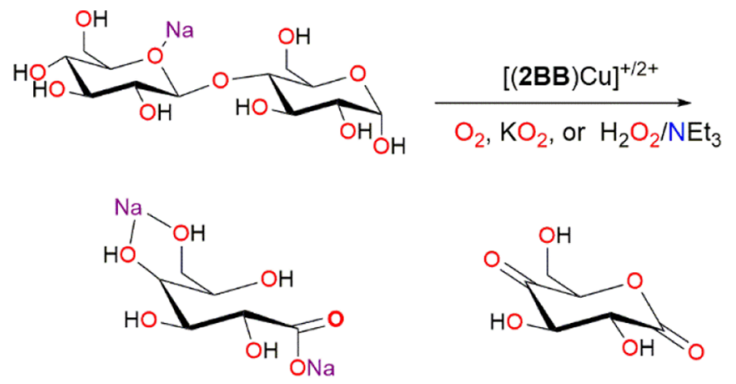

are observed (i.e., $\mathrm{H}_{2} \mathrm{O}_{2}$ is a more active but less selective oxidant, Figures S16-S18, Tables S6-S8). Reactions were also performed using in situ-reduced cupric complex (with 1.2 and 2.4 equiv ascorbate) and $\mathrm{KO}_{2}$ as an oxidizing agent, with similar degradation products detected, along with unreacted cellobiose (Table 2). Control experiments with [(2BB)$\left.\mathrm{Cu}^{\mathrm{II}}\left(\mathrm{H}_{2} \mathrm{O}\right)_{2}\right](\mathrm{OTf})_{2}, \mathrm{CuSO}_{4}, \mathrm{H}_{2} \mathrm{O}_{2} / \mathrm{NEt}_{3}$, and $\mathrm{CuSO}_{4} / \mathrm{H}_{2} \mathrm{O}_{2} /$ $\mathrm{NEt}_{3}$ show no oxidative degradation of cellobiose, although a previously observed dehydration product was detected at $\mathrm{m} / \mathrm{z}$ 334 in the first case. Care must be exercised in the interpretation of chromatograms, since all samples containing $\mathrm{H}_{2} \mathrm{O}_{2}$ have a leaching product from the HPLC column (Figure S19).

Glucose oxidation was tested in $\mathrm{PB}$ with $0.3 \mathrm{mM}$ $\left[(2 \mathrm{BB}) \mathrm{Cu}^{\mathrm{II}}\left(\mathrm{H}_{2} \mathrm{O}\right)_{2}\right](\mathrm{OTf})_{2}$ and 10 equiv of $\mathrm{H}_{2} \mathrm{O}_{2} / \mathrm{NEt}_{3}$ (Figure S20 and Table S9), resulting in mono-oxidation as the major product relative to double oxidation (33 vs $14 \%$ ). In addition to unreacted glucose, sodium gluconate and glucose aldehyde were detected in small quantities (Table 2). The only precedent of related inorganic systems capable of cleaving glucose derivatives features 4-nitrophenolate as the leaving group. $^{7 b, c}$

Computational Studies. The thermodynamic feasibility of the copper-oxygen species that may be formed in the presence of the oxidants tested $\left(\mathrm{O}_{2}, \mathrm{KO}_{2}\right.$, and $\left.\mathrm{H}_{2} \mathrm{O}_{2}\right)$ was evaluated by density functional studies. Reactions of [(2BB)$\left.\mathrm{Cu}^{\mathrm{I}}\right]^{+},\left[(2 \mathrm{BB}) \mathrm{Cu}^{\mathrm{II}}\right]^{2+},\left[(\mathbf{2 B B}) \mathrm{Cu}^{\mathrm{I}}(\mathrm{S})\right]^{+}$, and $\left[(2 \mathrm{BB}) \mathrm{Cu}^{\mathrm{II}}(\mathrm{S})\right]^{2+}$ $\left(\mathrm{S}=\mathrm{H}_{2} \mathrm{O}, \mathrm{CH}_{3} \mathrm{CN}\right.$ ) with dioxygen, potassium superoxide, or hydrogen peroxide were evaluated as they appear to generate the dimeric $\left[\left\{(2 \mathrm{BB}) \mathrm{Cu}^{\mathrm{II}}\right\}_{2}\left(\mu-\eta^{2}: \eta^{2}-\mathrm{O}_{2}\right)\right]^{2+}$ and potentially $\left[\left\{(2 \mathrm{BB}) \mathrm{Cu}^{\mathrm{III}}\right\}_{2}(\mu-\mathrm{O})_{2}\right]^{2+}$. The optimized structures were validated by comparison of the bonding parameters obtained with those observed for the structurally characterized complexes.

Initial Complexes. $\left[(2 \mathrm{BB}) \mathrm{Cu}^{\mathrm{I}}\right]^{+}$and $\left[(2 \mathrm{BB}) \mathrm{Cu}^{\mathrm{II}}\right]^{2+}$ were considered with either a molecule of water or $\mathrm{CH}_{3} \mathrm{CN}$ coordinated, since those solvents were employed for physical measurements and reactivity tests. For both solvents, the coordination of one molecule is energetically favorable, with values between 3 and $30 \mathrm{kcal} \mathrm{mol}^{-1}$ (Table 3). The Gibbs free energies for the solvent-coordinated cuprous complexes notwithstanding, calculated for $\left[(2 \mathrm{BB}) \mathrm{Cu}^{\mathrm{I}}\left(\mathrm{H}_{2} \mathrm{O}\right)\right]^{+}$and $\left[(2 \mathrm{BB}) \mathrm{Cu}^{\mathrm{I}}\left(\mathrm{NCCH}_{3}\right)\right]^{+}$at -3 and $-5 \mathrm{kcal} \mathrm{mol}^{-1}$, are rather low compared with the binding constants calculated for their cupric counterparts. This is consistent with the lack of experimental evidence for coordinated solvent molecules in the solid state or in solution by ESI-MS, which can be attributed to the high lability of the $\mathrm{Cu}(\mathrm{I})$ centers. The geometries of $\left[(2 \mathrm{BB}) \mathrm{Cu}^{\mathrm{I}}\right]^{+}$and the related solvent-coordinated $\left[(\mathbf{2 B B}) \mathrm{Cu}^{\mathrm{I}}\left(\mathrm{H}_{2} \mathrm{O}\right)\right]^{+}$were optimized, and their main geometrical parameters are shown in Table S11. Initial optimization was probed with $\left[(\mathbf{2 B B}) \mathrm{Cu}^{\mathrm{I}}\right]^{+}$and subsequently tested with one $\mathrm{H}_{2} \mathrm{O}$ ligand, revealing that the nitrogen atoms are maintained in a planar configuration. In the resulting $\left[(2 \mathrm{BB}) \mathrm{Cu}^{\mathrm{I}}\left(\mathrm{H}_{2} \mathrm{O}\right)\right]^{+}$, the cuprous center should be defined as four-coordinate but the calculated distance of the nitrogen atom from the central amine to the $\mathrm{Cu}^{+}$ion is considerably longer than in the absence of a bound $\mathrm{H}_{2} \mathrm{O}$ (2.407 vs $2.940 \AA$ ).

Redox Properties. The redox potentials for [(2BB)$\left.\mathrm{Cu}^{\mathrm{II} / \mathrm{I}}\right]^{2+/+}, \quad\left[(\mathbf{2 B B}) \mathrm{Cu}\left(\mathrm{CH}_{3} \mathrm{CN}\right)^{\mathrm{II} / \mathrm{I}}\right]^{2+/+}$, and $[(2 \mathbf{B B}) \mathrm{Cu}-$ $\left.\left(\mathrm{H}_{2} \mathrm{O}\right)^{\mathrm{II} / \mathrm{I}}\right]^{2+/+}$ couples were estimated by simulating the oxidation process in an acetonitrile solution and referenced to the ferrocenium/ferrocene couple. ${ }^{31}$ The calculated potential for trigonal $\left[(2 \mathbf{B B}) \mathrm{Cu}^{\mathrm{II} / \mathrm{I}}\right]^{2+/+}$ was $219 \mathrm{mV}$, which differs significantly from that calculated with one coordinated molecule of acetonitrile $(-135 \mathrm{mV})$ or water $(-305 \mathrm{mV})$. Since the latter values with solvent coordinated to the copper centers are reasonably close to the experimentally determined data in acetonitrile solution $\left(E_{1 / 2}=-272 \mathrm{mV}\right)$, solvent coordination seems to be plausible. In all cases, redox pairs involve a metal-centered process, i.e., the $\mathrm{Cu}^{\mathrm{II} / \mathrm{I}}$ couple.

Dimeric Species. During our attempts to detect copperoxygen species that may be responsible for the oxidation of cellobiose, the main candidates are the dicopper(II) species $\left[\left\{(\mathbf{B B B}) \mathrm{Cu}^{\mathrm{II}}\right\}_{2}\left(\mu-\eta^{2}: \eta^{2}-\mathrm{O}_{2}\right)\right]^{2+}$ and derivatives having acetate co-ligands. Since several geometries for $\mathrm{Cu}_{2} \mathrm{O}_{2}$ cores have been described in the literature, ${ }^{10,28-30}$ different conformations of the ligands were considered in the molecular optimization of

Table 2. Product Distribution in Cellobiose Degradation Reactions (\% Yield by HPLC Integration Relative to Cellobiose)

\begin{tabular}{|c|c|c|c|c|}
\hline \multirow[b]{3}{*}{ conditions } & \multicolumn{4}{|c|}{ assignment } \\
\hline & \multicolumn{2}{|c|}{ cellobiose degradation } & \multicolumn{2}{|c|}{ glucose degradation } \\
\hline & $\begin{array}{c}\mathrm{O}_{2}+\mathrm{Cu}(\mathrm{I})+10 \text { equiv sodium ascorbate } \\
\left(\mathrm{H}_{2} \mathrm{O}\right)\end{array}$ & $\begin{array}{c}\mathrm{H}_{2} \mathrm{O}_{2} / \mathrm{Et}_{3} \mathrm{~N}+\mathrm{Cu}(\mathrm{II}) \\
\left(\mathrm{CH}_{3} \mathrm{CN}\right)\end{array}$ & $\begin{array}{c}\mathrm{H}_{2} \mathrm{O}_{2} / \mathrm{Et}_{3} \mathrm{~N}+\mathrm{Cu}(\mathrm{II}) \\
(\mathrm{PB})\end{array}$ & $\begin{array}{c}\mathrm{H}_{2} \mathrm{O}_{2} / \mathrm{Et}_{3} \mathrm{~N}+\mathrm{Cu}(\mathrm{II}) \\
(\mathrm{PB})\end{array}$ \\
\hline$\%[\mathrm{Na}+\text { cellobiose }]^{+}$ & 65 & 8 & & \\
\hline$\%[\mathrm{Na}+\text { cellobiose- } 2 \mathrm{OH}]^{+}$ & 28 & 70 & & \\
\hline$\%[\mathrm{Na}+\text { glucose }]^{+}$ & & & & 13 \\
\hline$\%[2 \mathrm{Na}+\text { gluconate }]^{+}$ & 5 & 3 & 2 & 1 \\
\hline $\mathrm{X} \%[\text { doubly oxidized glucose }+\mathrm{H}]^{+}$ & & & 18 & 14 \\
\hline$\%[\text { oxidized glucose }+ \text { cellobiose }+\mathrm{H}]^{+}$ & & & 15 & 33 \\
\hline $\begin{array}{l}\%[\mathrm{Na}+\text { doubly oxidized glucose }+ \\
\left.2 \mathrm{H}_{2} \mathrm{O}\right]^{+}\end{array}$ & & & 37 & \\
\hline$\%[\mathrm{Na}+\text { glucose aldehyde }]^{+}$ & & & 10 & 5 \\
\hline
\end{tabular}


Table 3. Free Energies of Formation of $\left[(2 \mathrm{BB}) \mathrm{Cu}^{\mathrm{I}}(\mathrm{S})\right]^{+}$and $\left[(2 \mathrm{BB}) \mathrm{Cu}^{\mathrm{II}}(\mathrm{S})\right]^{2+}$ with $\mathrm{S}=\mathrm{H}_{2} \mathrm{O}$ or $\mathrm{CH}_{3} \mathrm{CN}$

$$
\begin{aligned}
& \text { reactions } \\
& {[(\mathbf{2 B B}) \mathrm{Cu}]^{+}+\mathrm{CH}_{3} \mathrm{CN} \rightarrow\left[(\mathbf{2 B B}) \mathrm{Cu}\left(\mathrm{CH}_{3} \mathrm{CN}\right)\right]^{+}} \\
& {[(\mathbf{2 B B}) \mathrm{Cu}]^{2+}+\mathrm{CH}_{3} \mathrm{CN} \rightarrow\left[(\mathbf{2 B B}) \mathrm{Cu}\left(\mathrm{CH}_{3} \mathrm{CN}\right)\right]^{2+}} \\
& {[(\mathbf{2 B B}) \mathrm{Cu}]^{+}+\mathrm{H}_{2} \mathrm{O} \rightarrow\left[(\mathbf{2 B B}) \mathrm{Cu}\left(\mathrm{H}_{2} \mathrm{O}\right)\right]^{+}} \\
& {[(\mathbf{2 B B}) \mathbf{C u}]^{2+}+\mathrm{H}_{2} \mathrm{O} \rightarrow\left[(\mathbf{2 B B}) \mathrm{Cu}\left(\mathrm{H}_{2} \mathrm{O}\right)\right]^{2+}}
\end{aligned}
$$

$\Delta G$ (gas phase)
-11.2
-30.9
-8.9
-26.6
$\Delta G\left(\mathrm{CH}_{3} \mathrm{CN}\right)$ $-4.8$

$-16.8$

$-3.1$

$-19.0$ dicopper species (Figure S21). Their relative energies in acetonitrile were calculated (Table S12) and, as expected, the bimetallic complexes were found to be more stable than the mononuclear $\mathrm{T}$-shape $\mathrm{Cu}(\mathrm{I})$ complex by more than $20 \mathrm{kcal}$ $\mathrm{mol}^{-1}$ in $\mathrm{CH}_{3} \mathrm{CN}$. Nevertheless, the presence of acetate modifies the dioxygen coordination around the metal centers, predicting the additional species $\left[\left\{(\mathbf{2 B B}) \mathrm{Cu}^{\mathrm{II}}\right\}_{2}\left(\mu-\eta^{1}: \eta^{1}\right.\right.$ $\left.\left.\mathrm{O}_{2}\right)(\mu-\mathrm{AcO})\right]^{+}$.

UV-vis spectra were calculated for complexes with and without acetate as co-ligand (Figure S22). Apparently, coordination of a bridging acetate does not alter the main electronic transitions in the bimetallic complexes. For $\left[\left\{(\mathbf{2 B B}) \mathrm{Cu}^{\mathrm{II}}\right\}_{2}\left(\mu-\eta^{2}: \eta^{2}-\mathrm{O}_{2}\right)\right]^{2+}$, an intense band around 330 $\mathrm{nm}$ with a $\mathbf{2 B B}$ to dioxygen charge-transfer character was calculated, together with a weaker one at $420 \mathrm{~nm}$ having an MLCT character; the first band is consistent with the experimentally observed absorption at $365 \mathrm{~nm}$. For optimized $\left[\left\{(\mathbf{2 B B}) \mathrm{Cu}^{\mathrm{II}}\right\}_{2}\left(\mu-\eta^{1}: \eta^{1}-\mathrm{O}_{2}\right)(\mu-\mathrm{AcO})\right]^{+}$in Figure S21 (species D), a medium intensity band is predicted at $420 \mathrm{~nm}$, although the one predicted at around $650 \mathrm{~nm}$ is not observed experimentally (Figures S22 and S23); assignment of $\left[\left\{(2 \mathrm{BB}) \mathrm{Cu}^{\mathrm{II}}\right\}_{2}\left(\mu-\eta^{1}: \eta^{1}-\mathrm{O}_{2}\right)(\mu-\mathrm{AcO})\right]^{+}$is only tentative without experimental verification.

\section{CONCLUSIONS}

$\left[(\mathbf{2 B B}) \mathrm{Cu}^{\mathrm{I}}\right]^{+}$acts as a structural and electronic model of the reduced site of LPMO enzymes. Speciation studies at different $\mathrm{pH}$ values, together with electrochemical and mass spectrometry measurements at $\mathrm{pH} 9.0-10.5$, allow us to establish that the $\mathrm{p} K_{\mathrm{a}}$ of water molecules bound to $2 \mathrm{BB}$-coordinated cupric centers is lower than that of the ligand-based amine moiety; this observation is relevant to the enzymatic system, where the proposed deprotonation of the amine of the histidine brace appears to be precluded.

Oxidative cleavage of cellobiose, which was employed as a model polysaccharide substrate, could be effected in the presence of $\left[(2 \mathbf{B B}) \mathrm{Cu}^{\mathrm{I}}\right]^{+}$or $\left[(\mathbf{2 B B}) \mathrm{Cu}^{\mathrm{II}}\left(\mathrm{H}_{2} \mathrm{O}\right)_{2}\right]^{2+}$ under appropriate conditions. Clear identification of a copperoxygen species responsible for the $\mathrm{C}-\mathrm{H}$ activation that leads to the oxidative cleavage of cellobiose was not possible via lowtemperature UV-vis absorption, MS, Raman, or EPR spectroscopic methods in $\mathrm{CH}_{3} \mathrm{CN}$ or $\mathrm{PB}$. However, the detection of potential reactive intermediates by ESI-MS, as well as $\left[(2 \mathbf{B B}) \mathrm{Cu}^{\mathrm{II}}(\mathrm{OH})\left(\mathrm{H}_{2} \mathrm{O}\right)\right]^{+}$as the common end product, provides some clues regarding the mechanistic possibilities outlined in Scheme 2.

Moreover, when a more reduced source of the oxidizing agent is provided in our system (i.e., $\mathrm{H}_{2} \mathrm{O}_{2}$ vs $\mathrm{O}_{2}$ ), more degradation of cellobiose was observed by HPLC-MS on a preparative scale, at a cost of lower selectivity. This is consistent with the tentative mechanisms that have been proposed for LPMOs, which imply $\mathrm{Cu}(\mathrm{I}) / \mathrm{H}_{2} \mathrm{O}_{2}$ as the most competent combination ${ }^{32}$ and $\mathrm{H}_{2} \mathrm{O}_{2}$ as the natural oxidant for polysaccharide degradation. ${ }^{6}$ Nonetheless, identification of the reactive copper-oxygen species involved in the key $\mathrm{C}-\mathrm{H}$ activations remains a major challenge in copper bioinorganic chemistry.

\section{EXPERIMENTAL SECTION}

All synthetic procedures were performed under a dry dinitrogen atmosphere in a glovebox or by conventional Schlenk techniques. THF and diethyl ether were obtained by oxygen- and water-free distilling from sodium benzophenone under a $\mathrm{N}_{2}$ atmosphere; acetonitrile was distilled from $\mathrm{CaH}_{2}$. Reagents were purchased from commercial suppliers and used as received; $\mathbf{2} \mathbf{B B}^{10 \mathrm{~b}, 13}$ and $\left[(\mathbf{2 B B}) \mathrm{Cu}^{\mathrm{II}}\left(\mathrm{H}_{2} \mathrm{O}\right)_{2}\right](\mathrm{OTf})_{2}{ }^{14,15}$ were synthesized according to literature procedures. ${ }^{1} \mathrm{H}$ and ${ }^{13} \mathrm{C}$ NMR spectra were recorded on a JEOL Eclipse 300 or a Bruker Avance DRX spectrometer at 300 and $75 \mathrm{MHz}$ or 500 and $125 \mathrm{MHz}$, respectively, using the residual protiated solvent signal or TMS as internal references (TMS $\delta=0.00, \mathrm{CHCl}_{3} \delta$ $=7.26 \mathrm{ppm}$ ). Electrospray ionization mass spectrometry (ESIMS) experiments were performed with a JEOL JMS-AX505HA spectrometer. Positive-ion $\mathrm{FAB}^{+}$mass spectra were acquired using a JEOL JMS-SX-102A mass spectrometer operated at an accelerating voltage of $10 \mathrm{kV}$ from a nitrobenzyl alcohol matrix by using xenon atoms at $6 \mathrm{keV}$. Cryospray ionization mass spectra were recorded on a Bruker MicrOTOF-Q II instrument at Serveis Tècnics of the University of Girona. Samples were introduced into the mass spectrometer ion source by direct infusion using a syringe pump and were externally calibrated using sodium formate. A cryospray attachment was used. Temperature of the nebulizing and drying gases was set at $-30{ }^{\circ} \mathrm{C}$. The instrument was operated in both positive- and negative-ion modes.

X-ray Crystallography. A single crystal of [(2BB) $\left.\mathrm{Cu}^{\mathrm{I}}\right]$ OTf mounted on a glass fiber was studied with an Oxford Diffraction Gemini "A" diffractometer and a CCD area detector $\left(\lambda_{\mathrm{MoK} \alpha}=0.71073 \AA\right.$, monochromator: graphite) source equipped with a sealed tube X-ray source at $130 \mathrm{~K}$. Unit cell constants were determined with a set of $15 / 3$ narrow frame/run $\left(1^{\circ}\right.$ in $\left.\omega\right)$ scans. A data set consisted of 235 frames of intensity data collected and a crystal-to-detector distance of $55.00 \mathrm{~mm}$. The double pass method of scanning was used to exclude any noise. The collected frames were integrated by using an orientation matrix determined from the narrow frame scans. CrysAlisPro and CrysAlis RED software packages were used for data collection and data integration. ${ }^{33}$ Analysis of the integrated data did not reveal any decay. Final cell constants were determined by a global refinement of 12733 reflections $\left(\theta<29.51^{\circ}\right)$. Collected data were corrected for absorbance by using analytical numeric absorption correction using a multifaceted crystal model based on expressions upon the Laue symmetry using equivalent reflections. ${ }^{34}$ Structure solution and refinement were carried out with SHELXS$2014^{35 a}$ and SHELXL-2014; ${ }^{35 b}$ WinGX v2014.1 software $^{36}$ was used to prepare material for publication. Full-matrix leastsquares refinement was carried out by minimizing $\left(F_{o}{ }^{2}-F_{c}{ }^{2}\right)^{2}$. All nonhydrogen atoms were refined anisotropically. The $\mathrm{H}$ atom of the amine group $(\mathrm{H}-\mathrm{N})$ was located in the difference 
map and refined isotropically with $U_{\text {iso }}(\mathrm{H})=1.2$ for $\mathrm{H}-\mathrm{N}$. $\mathrm{H}$ atoms attached to $\mathrm{C}$ atoms were placed in geometrically idealized positions and refined as riding on their parent atoms, with $\mathrm{C}-\mathrm{H}=0.95-0.99 \AA$ and with $U_{\text {iso }}(\mathrm{H})=1.2 U_{\text {eq }}(\mathrm{C})$ for aromatic and methylene groups and $U_{\text {iso }}(\mathrm{H})=1.5 U_{\text {eq }}(\mathrm{C})$ for methyl groups. A summary of crystallographic data is presented in Tables S1-S3, Supporting Information. Crystallographic data have been deposited at the Cambridge Crystallographic Data Centre CCDC 1821707.

Computational Details. Unrestricted calculations were carried out using the Gaussian 09 package. ${ }^{37}$ The hybrid density functional method known as B3LYP was applied. ${ }^{38}$ Effective core potentials were used to represent the innermost electrons of the transition-metal atoms and the valence double$\zeta$ quality basis set LANL2DZ associated with the pseudopotentials. ${ }^{39}$ The basis set used for the main group elements was 6-31G*. ${ }^{40}$ Solvent effects were taken into account through PCM calculations (acetonitrile, $\varepsilon=36.64$ and water, $\varepsilon=$ $78.3553)^{41}$ by using the geometries optimized for the gas phase (single-point calculations). Gibbs free energies in solution were calculated from a thermodynamic cycle of the chemical process by adding solvent effects. Redox potentials were estimated from these solvent calculations by using as reference a value of $5.08 \mathrm{~V}$ for the absolute standard hydrogen electrode (SHE) in acetonitrile. ${ }^{42}$ The geometrical parameters were analyzed using the SHAPE program. ${ }^{43}$

Vertical excitation energies were obtained from TD-DFT, as implemented in Gaussian 09 in the presence of solvent (acetonitrile). Calculations were performed at the same computational level as singlet states for the dimeric species, using the broken-symmetry approach. Closed-shell singlet and triplet states were also calculated, with small differences.

Electrochemistry. Cyclic voltammetry measurements were made under $\mathrm{N}_{2}$ in anhydrous $\mathrm{CH}_{3} \mathrm{CN}$, carbonate buffer solution at $\mathrm{pH} 10.5$, or phosphate buffer solutions at $\mathrm{pH}=5.0$, 7.0, and 9.0, with a $\mathrm{CH}$ Instruments potentiostat-galvanostat equipped with a glassy carbon working electrode and a platinum wire auxiliary electrode. Potentials were recorded versus a pseudoreference electrode of $\mathrm{AgBr}(\mathrm{s}) / \mathrm{Ag}$ (wire) immersed in $0.1 \mathrm{M} \mathrm{NBu}_{4} \mathrm{Br}$ acetonitrile or distilled water solutions. All voltammograms were started from the current null potential $\left(E_{\mathrm{i}}=0\right)$ and were scanned in both directions, positive and negative, and obtained at scan rates of 0.10 and $0.20 \mathrm{~V} \mathrm{~s}^{-1}$. In agreement with IUPAC convention, the voltammogram of the ferrocenium-ferrocene $\left(\mathrm{Fc}^{+} / \mathrm{Fc}\right)$ system $^{31}$ was obtained to establish the values of half wave potentials $\left(E_{1 / 2}\right)$ from the expression $E_{1 / 2}=\left(E_{\mathrm{a}}+E_{\mathrm{c}}\right) / 2$. To obtain the normalized current for each complex, the measured current was divided by the exact molar concentration of the electroactive species.

Solution Studies. For potentiometric titrations, the electrode was calibrated in water, using standard buffers at $25{ }^{\circ} \mathrm{C}$. Commercial $0.1 \mathrm{M} \mathrm{NaOH}$ standard solutions were employed, after determination of carbonates present using the Gran Method, ensuring that their concentration was below 5\%. The solution of $\mathrm{HNO}_{3}$ at $8 \mathrm{mM}$ concentration was prepared directly from concentrated acid. Potassium biphthalate was used as an internal standard (oven vacuum-drying $24 \mathrm{~h}$ prior to use).

The analytes $2 \mathbf{B B}$ and of $\left[(\mathbf{2 B B}) \mathrm{Cu}^{\mathrm{II}}\left(\mathrm{H}_{2} \mathrm{O}\right)_{2}\right](\mathrm{OTf})_{2}$ were acidified in a 1:8 ratio with respect to $\mathrm{HNO}_{3}$ to ensure complete protonation, maintaining in each case a concentration of $1.21 \times 10^{-3} \mathrm{~mol} \mathrm{~L}^{-1}$. The solutions were maintained in a special cell at $25{ }^{\circ} \mathrm{C}$, stirred under a nitrogen atmosphere, controlling the ionic strength at $0.1 \mathrm{M}$ with $\mathrm{NaNO}_{3}$ under homogeneous conditions. Potentiometric data were obtained in triplicate for acid, base, internal standard, and analytes using a 702SM Titrino automatic titrator and TIAMO1.3 software; for each triplicate, the standard deviation was determined and the final values were averaged. Hyperquad ${ }^{18}$ was employed to simulate the data obtained, so that the constants adjusted the model with $\chi^{2}$ lower than 12.6 with $95 \%$ confidence and the species distribution was determined with MEDUSA. ${ }^{19}$

Synthesis of $[(2 \mathrm{BB}) \mathrm{Cu}]$ OTf. In an inert atmosphere glovebox, 2BB (100 mg, $0.30 \mathrm{mmol})$ and $\left[\mathrm{Cu}^{\mathrm{I}}\left(\mathrm{NCCH}_{3}\right)_{4}\right] \mathrm{OTf}$ $(113 \mathrm{mg}, 0.30 \mathrm{mmol}$ ) were dissolved in $10 \mathrm{~mL}$ of anhydrous $\mathrm{CH}_{3} \mathrm{CN}$; after $3 \mathrm{~h}$, volatiles were evaporated under reduced pressure and the solid obtained was washed with $10 \mathrm{~mL}$ of anhydrous diethyl ether to afford colorless microcrystalline [(2BB) $\mathrm{Cu}^{\mathrm{I}}$ ] OTf $(39 \mathrm{mg})$ : Yield: $24 \%$; mp $150-152{ }^{\circ} \mathrm{C} ;{ }^{1} \mathrm{H}$ NMR $\left(300 \mathrm{MHz}, \mathrm{CD}_{3} \mathrm{CN}\right): \delta 7.64(\mathrm{~s}, 5 \mathrm{H}, \mathrm{Ar}), \delta 7.24(\mathrm{~s}, 1 \mathrm{H}$, $\mathrm{Ar}), \delta 7.06(\mathrm{p}, J=7.2 \mathrm{~Hz}, 5 \mathrm{H}, \mathrm{Ar}), \delta 4.97(\mathrm{dd}, J=13.4,3.3 \mathrm{~Hz}$, $1 \mathrm{H}, \mathrm{NH}), \delta 3.42\left(\mathrm{~m}, 7 \mathrm{H}, \mathrm{N}\right.$-methyl), $\delta 3.21\left(\mathrm{~m}, 1 \mathrm{H}, \mathrm{CH}_{2} \mathrm{~N}-\right.$ ), $\delta 3.01\left(\mathrm{dt}, J=40.4,20.2 \mathrm{~Hz}, 4 \mathrm{H}, \mathrm{CH}_{2} \mathrm{C}-\right)$; ESI-MS $\mathrm{m} / z$ : $\left[(\mathbf{2 B B}) \mathrm{Cu}^{\mathrm{I}}\right]^{+}=396,\left[(\mathbf{2 B B}) \mathrm{Cu}^{\mathrm{I}}(\mathrm{OTf})\right]^{+}=545 ; \mathrm{UV}-\mathrm{vis}$ $\left(\mathrm{CH}_{3} \mathrm{CN}\right): 264$ (1744), 270 (1577), 282 (7044); IR (KBr): $3273,2957,2906,2852,1614,1503,1481,1452,1410,1327$, $1257,1227,1147,1067,1027,974,936,850,825,750,656$, $633,570,515,455,434$; elemental analysis calcd (\%) for $\mathrm{C}_{21} \mathrm{H}_{22} \mathrm{CuF}_{3} \mathrm{~N}_{5} \mathrm{O}_{3} \mathrm{~S}: \mathrm{C}, 46.28 ; \mathrm{H}, 4.07 ; \mathrm{N}, 12.85$; found: $\mathrm{C}$, $46.71 ; \mathrm{H}, 4.15 ; \mathrm{N}, 12.75$.

Reactivity Studies. The reactivity studies that were carried out with the 2BB-copper complexes were monitored by UVvis, ESI-MS, and EPR:

For UV-vis, a $0.3 \mathrm{mM}$ concentration solution of the complex under study was prepared, $2.5 \mathrm{~mL}$ was transferred to a $1 \mathrm{~cm}$ optical path cell (Schlenk type in the case of cuprous complex, which was sealed with a rubber septum). The cell was transferred to a precooled cryostat and chilled to 243 or $273 \mathrm{~K}$, depending on the solvent used $\left(\mathrm{CH}_{3} \mathrm{CN}, \mathrm{PB} \mathrm{pH} 7.0\right)$, with 10 min allowed for equilibration prior to reaction. Oxygenation of the cuprous complex was achieved by gently bubbling dioxygen through the solution using a long needle for $50 \mathrm{~s}$; addition of $\mathrm{KO}_{2}, \mathrm{H}_{2} \mathrm{O}_{2} 35 \%$, or $\mathrm{H}_{2} \mathrm{O}_{2} / \mathrm{Et}_{3} \mathrm{~N}$ dissolved in $\mathrm{CH}_{3} \mathrm{CN}, \mathrm{H}_{2} \mathrm{O}$, or a $\mathrm{MeOH} / \mathrm{CH}_{3} \mathrm{CN}$ mixture (2:3) was performed with 1 equiv of the oxidizing agent in $2 \mu \mathrm{L}$ of solvent. The stability of the formed species was monitored every 5 min over a period of an hour by measuring the absorbance. Reversibility of each generated system was also determined by bubbling Ar through the solution for $50 \mathrm{~s}$ using a long needle. Once the copperoxygen species was formed, 10 equiv of cellobiose as a substrate was added while stirring in $20 \mu \mathrm{L}$ of water or a $2: 3$ $\mathrm{H}_{2} \mathrm{O} / \mathrm{CH}_{3} \mathrm{CN}$ mixture; the samples were monitored every 5 min over a period of $40 \mathrm{~min}$ by measuring the absorbance. The same samples were injected in ESI-MS spectrometers under appropriate conditions.

Characterization by $\mathrm{X}$-band electron spin resonance (EPR) spectroscopy was undertaken in frozen acetonitrile or $\mathrm{PB} \mathrm{pH}$ 7.0/glycerol. Two hundred microliters of a $3 \mathrm{mM}$ stock solution of the cuprous or cupric complex in $\mathrm{CH}_{3} \mathrm{CN}$ or $\mathrm{PB} /$ glycerol were placed in quartz EPR tubes $\left(\left[(\mathbf{2 B B}) \mathrm{Cu}^{\mathrm{I}}\right] \mathrm{OTf}\right.$ was prepared in a dinitrogen-filled glovebox) and were sealed with rubber septa. Samples were frozen in liquid nitrogen before acquisition at $77 \mathrm{~K}$ for $\mathrm{CH}_{3} \mathrm{CN}$ and $\mathrm{PB}$ /glycerol. The tubes were warmed in ice (273 for PB solution) or ice/acetone (243 $\mathrm{K}$ for $\mathrm{CH}_{3} \mathrm{CN}$ solution) baths until the samples became 
fluid. Oxygenation of cuprous complexes was achieved by bubbling $\mathrm{O}_{2}$ through the solutions using a long needle for $50 \mathrm{~s}$. The oxidizing agents used were as follows: $\mathrm{KO}_{2}$ in $1: 1$ methanol/acetonitrile or $\mathrm{H}_{2} \mathrm{O} ; \mathrm{H}_{2} \mathrm{O}_{2}$, or $\mathrm{H}_{2} \mathrm{O}_{2} / \mathrm{Et}_{3} \mathrm{~N}$, maintaining 1 equiv of the oxidizing agent in $2 \mu \mathrm{L}$ of solution. After addition, spectra were acquired again at 77 or $133 \mathrm{~K}$, respectively. After formation of copper-oxygen species, 10 equiv of cellobiose dissolved in $20 \mu \mathrm{L}$ of water or a $2: 3$ $\mathrm{MeOH} / \mathrm{CH}_{3} \mathrm{CN}$ mixture was added and the spectra were acquired again at $77 \mathrm{~K}$. In situ generation of the $\mathrm{Cu}(\mathrm{I})$ complex from $\left[(2 \mathbf{B B}) \mathrm{Cu}^{\mathrm{II}}\left(\mathrm{H}_{2} \mathrm{O}\right)_{2}\right](\mathrm{OTf})_{2}$ was achieved by adding 1.2 equiv of sodium ascorbate in $20 \mu \mathrm{L}$ of distilled water or a $2: 3$ $\mathrm{MeOH} / \mathrm{CH}_{3} \mathrm{CN}$ mixture.

Raman spectra at 355 and $405 \mathrm{~nm}$ were recorded at $-30{ }^{\circ} \mathrm{C}$ (QNW temperature control cell holder) and room temperature. Raman spectra recorded at 355 (10 mW Cobalt lasers) and 457 (50 $\mathrm{mW}$ Cobalt lasers) $\mathrm{nm}$ used a home-built system in which the laser was focused on the sample in a $180^{\circ}$ backscattering arrangement and Raman scattering was collected, collimated, and subsequently refocused via a pair of $2.5 \mathrm{~cm}$ diameter planoconvex lens $(f=15$ and $10 \mathrm{~cm}$, respectively). The collected light was filtered by an appropriate long pass edge filter (Semrock) and dispersed by a Shamrock500i spectrograph (slit width $80 \mu \mathrm{m}$, Andor Technology) with a $2400 \mathrm{~L} / \mathrm{mm}$ grating blazed at $300 \mathrm{~nm}$ and a Shamrock300i spectrograph (slit width $80 \mu \mathrm{m}$, Andor Technology) with a $1200 \mathrm{~L} / \mathrm{mm}$ grating blazed at $500 \mathrm{~nm}$, respectively. Data were recorded using Andor Solis (Andor Technology) with spectral calibration performed using the Raman spectrum of acetonitrile/toluene 50:50 (v/v). ${ }^{44}$ Samples were held in quartz $1 \mathrm{~cm}$ path length cuvettes. Spectra analysis and processing was performed using the program Spectragryph 1.2.11. ${ }^{45}$

Preparative Scale Cellobiose and Glucose Degradation. Studies were carried out with $3 \mathrm{~mL}$ of $2 \mathrm{BB}-\mathrm{Cu}$ complexes and 10 equiv of oxidizing agent or 1 atmosphere of $\mathrm{O}_{2}$ at $273 \mathrm{~K}(\mathrm{~PB})$ or $243 \mathrm{~K}\left(\mathrm{CH}_{3} \mathrm{CN}\right)$ and 10 equiv of cellobiose or glucose in $1 \mathrm{~mL}$ of distilled water. The mixtures were stirred for $2 \mathrm{~h}$ prior to characterization by HPLC-MS with an Agilent 1200 infinity Q-ToF spectrometer equipped with a Poroshell 120 column.

\section{ASSOCIATED CONTENT}

\section{S Supporting Information}

The Supporting Information is available free of charge on the ACS Publications website at DOI: 10.1021/acsomega.9b00785.

Materials, spectroscopic data, and methods; electrospray mass spectrum; summary of crystallographic data; bond lengths; cyclic voltammograms; UV-vis spectrum; general procedure for sample preparations in reactivity studies (PDF)

\section{AUTHOR INFORMATION}

\section{Corresponding Author}

*E-mail: joseivan@unam.mx.

ORCID $\odot$

Gabriel Aullón: 0000-0001-7519-4522

Anna Company: 0000-0003-4845-4418

Wesley R. Browne: 0000-0001-5063-6961

Ivan Castillo: 0000-0002-4876-4339

\section{Author Contributions}

The manuscript was written through contributions of all authors. All authors have given approval to the final version of the manuscript.

\section{Notes}

The authors declare no competing financial interest.

\section{ACKNOWLEDGMENTS}

The authors thank Carmen Márquez and Lucero Ríos for mass spectrometry, María de la Paz Orta for combustion analysis, Rocío Patiño for IR, and Virginia Gómez-Vidales for EPR determinations; G.A. and P.R.M.A. acknowledge IQTC-UB for computational resources; AC MINECO Spain CTQ201677989-P; A.C.N., E.N., and I.C., the Swedish Research Council (2014-0429); J.C., the Chinese Scholarship Council; J.B.K. and W.R.B., the Netherlands Ministry of Education, Culture and Science (Gravity Program 024.001.035); A.C.N. and I.C., DGAPA-PAPIIT (IN210214 and IN203317), CONACyT (Beca 293842), and CONACyT-ANUIES (ECOS 291247) for financial support.

\section{REFERENCES}

(1) (a) Phillips, C. M.; Beeson, W. T., IV; Cate, J. H.; Marletta, M. A. Cellobiose Dehydrogenase and a Copper-Dependent Polysaccharide Monooxygenase Potentiate Cellulose Degradation by Neurospora crassa. ACS Chem. Biol. 2011, 6, 1399. (b) Beeson, W. T.; Phillips, C. M.; Cate, J. H. D.; Marletta, M. A. Oxidative Cleavage of Cellulose by Fungal Copper-Dependent Polysaccharide Monooxygenases. J. Am. Chem. Soc. 2012, 134, 890.

(2) (a) Quinlan, R. J.; Sweeney, M. D.; Lo Leggio, L.; Otten, H.; Poulsen, J.-C. N.; Johansen, K. S.; Krogh, K. B. R. M.; Jorgensen, C. I.; Tovborg, M.; Anthonsen, A.; Tryfona, T.; Walter, C. P.; Dupree, P.; Xu, F.; Davies, G. J.; Walton, P. H. Insights into the oxidative degradation of cellulose by a copper metalloenzyme that exploits biomass components. Proc. Natl. Acad. Sci. U.S.A. 2011, 108, 15079. (b) Hemsworth, G. R.; Taylor, E. J.; Kim, R. Q.; Gregory, R. C.; Lewis, S. J.; Turkenburg, J. P.; Parkin, A.; Davies, G. J.; Walton, P. H. The Copper Active Site of CBM33 Polysaccharide Oxygenases. J. Am. Chem. Soc. 2013, 135, 6069. (c) Hemsworth, G. R.; Henrissat, B.; Davies, G. J.; Walton, P. H. Discovery and characterization of a new family of lytic polysaccharide mono-oxygenases. Nat. Chem. Biol. 2014, 10, 122.

(3) (a) Lieberman, R. L.; Rosenzweig, A. C. Crystal structure of a membrane-bound metalloenzyme that catalyses the biological oxidation of methane. Nature 2005, 434, 177. (b) Balasubramanian, R.; Smith, S. M.; Rawat, S.; Yatsunyk, L. A.; Stemmler, T. L.; Rosenzweig, A. C. Oxidation of methane by a biological dicopper centre. Nature 2010, 465, 115.

(4) Frandsen, K. E. H.; Simmons, T. J.; Dupree, P.; Poulsen, J.-C. N.; Hemsworth, G. R.; Ciano, L.; Johnston, E. M.; Tovborg, M.; Johansen, K. S.; von Freiesleben, P.; Marmuse, L.; Fort, S.; Cottaz, S.; Driguez, H.; Henrissat, B.; Lenfant, N.; Tuna, F.; Baldansuren, A.; Davies, G. J.; Lo Leggio, L.; Walton, P. H. The molecular basis of polysaccharide cleavage by lytic polysaccharide monooxygenases. Nat. Chem. Biol. 2016, 12, 298.

(5) Kjaergaard, C. H.; Qayyum, M. F.; Wong, S. D.; Xu, F.; Hemsworth, G. R.; Walton, D. J.; Young, N. A.; Davies, G. J.; Walton, P. H.; Johansen, K. S.; Hodgson, K. O.; Hedman, B.; Solomon, E. I. Spectroscopic and computational insight into the activation of $\mathrm{O}_{2}$ by the mononuclear $\mathrm{Cu}$ center in polysaccharide monooxygenases. Proc. Nat. Acad. Sci. U.S.A. 2014, 111, 8797.

(6) Bissaro, B.; Rohr, A. K.; Muller, G.; Chylenski, P.; Skaugen, M.; Forsberg, Z.; Horn, S. J.; Vaaje-Kolstad, G.; Eijsink, V. G. H. Oxidative cleavage of polysaccharides by monocopper enzymes depends on $\mathrm{H}_{2} \mathrm{O}_{2}$. Nat. Chem. Biol. 2017, 13, 1123. 
(7) (a) Neisen, B. D.; Gagnon, N. L.; Dhar, D.; Spaeth, A. D.; Tolman, W. B. Formally Copper(III)-Alkylperoxo Complexes as Models of Possible Intermediates in Monooxygenase Enzymes. J. Am. Chem. Soc. 2017, 139, 10220. (b) Concia, A. L.; Beccia, M. R.; Orio, M.; Ferre, F. T.; Scarpellini, M.; Biaso, F.; Guigliarelli, B.; Réglier, M.; Simaan, A. J. Copper Complexes as Bioinspired Models for Lytic Polysaccharide Monooxygenases. Inorg. Chem. 2017, 56, 1023. (c) Muthuramalingam, S.; Maheshwaran, D.; Velusamy, M.; Mayilmurugan, R. Regioselective oxidative carbon-oxygen bond cleavage catalysed by copper(II) complexes: A relevant model study for lytic polysaccharides monooxygenases activity. J. Catal. 2019, 372, 352.

(8) (a) Itoh, S. Developing Mononuclear Copper-Active-Oxygen Complexes Relevant to Reactive Intermediates of Biological Oxidation Reactions. Acc. Chem. Res. 2015, 48, 2066. (b) Quist, D. A.; Díaz, D. E.; Liu, J. J.; Karlin, K. D. Activation of dioxygen by copper metalloproteins and insights from model complexes. J. Biol. Inorg. Chem. 2017, 22, 253.

(9) (a) Thompson, L. K.; Ramaswamy, B. S.; Dawe, R. D. Nickel(II) and copper(II) complexes of the 'tripod' ligand tris(2benzimidazylmethyl)amine. Can. J. Chem. 1978, 56, 1311. (b) Addison, A. W.; Hendriks, H. M. J.; Reedijk, J.; Thompson, L. K. Copper complexes of the "tripod" ligand tris(2-benzimidazolylmethyl)amine: five- and six-coordinate copper(II) derivatives and some copper(I) derivatives. Inorg. Chem. 1981, 20, 103. (c) Balamurugan, R.; Palaniandavar, M.; Gopalan, R. S. Trigonal planar copper(I) complex: synthesis, structure, and spectra of a redox pair of novel copper(II/I) complexes of tridentate bis(benzimidazol-2'-yl) ligand framework as models for electron-transfer copper proteins. Inorg. Chem. 2001, 40, 2246. (d) Vaidyanathan, M.; Balamurugan, R.; Sivagnanam, U.; Palaniandavar, M. Synthesis, structure, spectra and redox of $\mathrm{Cu}(\mathrm{II})$ complexes of chelating bis(benzimidazole)-thioether ligands as models for electron transfer blue copper proteins. J. Chem. Soc., Dalton Trans. 2001, 3498. (e) Seo, M. S.; Kim, N. H.; Cho, K.-B.; So, J. E.; Park, S. K.; Clémancey, M.; Garcia-Serres, R.; Latour, J. -M; Shaik, S.; Nam, W. A mononuclear nonheme iron(IV)-oxo complex which is more reactive than cytochrome $\mathrm{P} 450$ model compound I. Chem. Sci. 2011, 2, 1039.

(10) (a) Casella, L.; Gullotti, M.; Radaelli, R.; Di Gennaro, P. A tyrosinase model system. Phenol ortho-hydroxylation by a binuclear three-coordinate copper(I) complex and dioxygen. J. Chem. Soc., Chem. Commun. 1991, 1611. (b) Casella, L.; Monzani, E.; Gullotti, M.; Gliubich, F.; De Gioia, L. Cytochrome c oxidase models: synthesis and reactivity of iron(III)-copper(II) complexes of deuterohaemin-polybenzimidazole dinucleating ligands. J. Chem. Soc., Dalton Trans. 1994, 3203. (c) Casella, L.; Monzani, E.; Gullotti, M.; Cavagnino, D.; Cerina, G.; Santagostini, L.; Ugo, R. Functional Modeling of Tyrosinase. Mechanism of Phenol orthoHydroxylation by Dinuclear Copper Complexes. Inorg. Chem. 1996, 35, 7516. (d) Garcia-Bosch, I.; Company, A.; Frisch, J. R.; TorrentSucarrat, M.; Cardellach, M.; Gamba, I.; Güell, M.; Casella, L.; Que, L., Jr.; Ribas, X.; Luis, J. M.; Costas, M. $\mathrm{O}_{2}$ Activation and Selective Phenolate ortho Hydroxylation by an Unsymmetric Dicopper $\mu$ $\eta 1: \eta 1$-Peroxido Complex. Angew. Chem., Int. Ed. 2010, 49, 2406.

(11) (a) Rodríguez Solano, L. A.; Aguiñiga, I.; López-Ortíz, M.; Tiburcio, R.; Luviano, A.; Regla, I.; Santiago-Osorio, E.; UgaldeSaldívar, V. M.; Toscano, R. A.; Castillo, I. Bis(2methylbenzimidazolyl)amine-Derived Copper Complexes and Their Antineoplastic Activity. Eur. J. Inorg. Chem. 2011, 3454. (b) Castillo, I.; Ugalde-Saldívar, V. M.; Rodríguez Solano, L. A.; Sánchez Eguía, B. N.; Zeglio, E.; Nordlander, E. Structural, spectroscopic, and electrochemical properties of tri- and tetradentate $\mathrm{N}_{3}$ and $\mathrm{N}_{3} \mathrm{~S}$ copper complexes with mixed benzimidazole/thioether donors. Dalton Trans. 2012, 41, 9394. (c) Martínez-Alanis, P. R.; Sánchez-Eguía, B. N.; Ugalde-Saldívar, V. M.; Regla, I.; Demare, P.; Aullón, G.; Castillo, I. Copper Versus Thioether-Centered Oxidation: Mechanistic Insights into the Non-Innocent Redox Behavior of Tripodal Benzimidazolylaminothioether Ligands. Chem. - Eur. J. 2013, 19, 6067. (d) SánchezEguía, B. N.; Flores-Alamo, M.; Orio, M.; Castillo, I. Side-on cupric- superoxo triplet complexes as competent agents for $\mathrm{H}$-abstraction relevant to the active site of PHM. Chem. Commun. 2015, 51, 11134. (12) Bacik, J.-P.; Mekasha, S.; Forsberg, Z.; Kovalevsky, A. Y.; VaajeKolstad, G.; Eijsink, V. G. H.; Nix, J. C.; Coates, L.; Cuneo, M. J.; Unkefer, C. J.; Chen, J. C. Neutron and Atomic Resolution X-ray Structures of a Lytic Polysaccharide Monooxygenase Reveal CopperMediated Dioxygen Binding and Evidence for N-Terminal Deprotonation. Biochemistry 2017, 56, 2529.

(13) Sorrell, T. N.; Vankai, V. A.; Garrity, M. L. Synthesis and reactivity of dinuclear copper complexes having a m-xylyl spacer between coordination units. Inorg. Chem. 1991, 30, 207.

(14) Casella, L.; Carugo, O.; Gullotti, M.; Doldi, S.; Frassoni, M. Synthesis, Structure, and Reactivity of model complexes of copper nitrite reductase. Inorg. Chem. 1996, 35, 1101.

(15) Castillo, I.; Neira, A. C.; Nordlander, E.; Zeglio, E. Bis(benzimidazolyl)amine copper complexes with a synthetic 'histidine brace' structural motif relevant to polysaccharide monooxygenases. Inorg. Chim. Acta. 2014, 422, 152.

(16) Frandsen, K. E. H.; Poulsen, J.-C. N.; Tandrup, T.; Lo Leggio, L. Unliganded and substrate bound structures of the cellooligosaccharide active lytic polysaccharide monooxygenase LsAA9A at low pH. Carbohydrate Res. 2017, 448, 187.

(17) (a) Lane, T. J.; Quinlan, R. Metal binding of the benzimidazoles. J. Am. Chem. Soc. 1960, 82, 2994. (b) Davies, M. T.; Mamalis, P.; Petrow, V.; Sturgeon, B. J. The preparation and spectrographic properties of some benziminazole-cobalt coordination compounds. J. Pharm. Pharmacol. 1951, 3, 420.

(18) Gans, P.; Sabatini, A.; Vacca, A. Investigation of equilibria in solution. Determination of equilibrium constants with the HYPERQUAD suite of programs. Talanta 1996, 43, 1739.

(19) Puigdomenech, I. MEDUSA: Make Equilibrium Diagrams Using Sophisticated Algorithms; KTH, Stockholm, 2009.

(20) Martin, R. B. Pyrrole hydrogen ionization of imidazole derivatives in metal ion complexes and carbonic anhydrase. Proc. Nat. Acad. Sci. U.S.A. 1974, 71, 4346.

(21) (a) Miyamoto, T.; Kamino, S.; Odani, A.; Hiromura, M.; Enomoto, S. Basicity of N-Terminal amine in ATCUN peptide regulates stability constant of albumin-like $\mathrm{Cu}^{2+}$ complex. Chem. Lett. 2013, 42, 1099. (b) Kandemir, B.; Kubie, L.; Guo, Y.; Sheldon, B.; Bren, K. L. Hydrogen evolution from water under aerobic conditions catalyzed by a cobalt ATCUN Metallopeptide. Inorg. Chem. 2016, 55, 1355.

(22) Caldararu, O.; Oksanen, E.; Ryde, U.; Hedegard, E. D. Mechanism of hydrogen peroxide formation by lytic polysaccharide monooxygenase. Chem. Sci. 2019, 10, 576.

(23) (a) Mukherjee, J.; Balamurugan, V.; Hundal, M. S.; Mukherjee, R. Fixation of $\mathrm{CO}_{2}$ in air: synthesis and crystal structure of a $\mu_{3}-\mathrm{CO}_{3}-$ bridged tricopper(II) compound. J. Chem. Sci. 2005, 117, 111. (b) Das, B.; Bhadbhade, M.; Thapper, A.; Ling, C. D.; Colbran, S. B. A new tri-nuclear $\mathrm{Cu}$-carbonate cluster utilizing $\mathrm{CO}_{2}$ as a C1-building block - reactive intermediates, a probable mechanism, and EPR and magnetic studies. Dalton Trans. 2019, 48, 3576.

(24) Fujii, T.; Yamaguchi, S.; Funahashi, Y.; Ozawa, T.; Tosha, T.; Kitagawa, T.; Masuda, H. Mononuclear copper(II)-hydroperoxo complex derived from reaction of copper(I) complex with dioxygen as a model of $\mathrm{D} \beta \mathrm{M}$ and PHM. Chem. Commun. 2006, 4428.

(25) Wada, A.; Harata, M.; Hasegawa, K.; Jitsukawa, K.; Masuda, H.; Mukai, M.; Kitagawa, T.; Einaga, H. Structural and Spectroscopic Characterization of a Mononuclear Hydroperoxo-Copper(II) Complex with Tripodal Pyridylamine Ligands. Angew. Chem., Int. Ed. 1998, 37, 798 .

(26) (a) Kodera, M.; Kita, T.; Miura, I.; Nakayama, N.; Kawata, T.; Kano, K.; Hirota, S. Hydroperoxo-Copper(II) Complex Stabilized by $\mathrm{N}_{3} \mathrm{~S}$-Type Ligand Having a Phenyl Thioether. J. Am. Chem. Soc. 2001, 123, 7715. (b) Maiti, D.; Lucas, H. R.; Narducci Sarjeant, A. A.; Karlin, K. D. Aryl Hydroxylation from a Mononuclear CopperHydroperoxo Species. J. Am. Chem. Soc. 2007, 129, 6998.

(27) Donoghue, P. J.; Tehranchi, J.; Cramer, C. J.; Sarangi, R.; Solomon, E. I.; Tolman, W. B. Rapid C-H Bond Activation by a 
Monocopper(III)-Hydroxide Complex. J. Am. Chem. Soc. 2011, 133, 17602 .

(28) (a) Baldwin, M. J.; Root, D. E.; Pate, J. E.; Fujisawa, K.; Kitajima, N.; Solomon, E. I. Spectroscopic studies of side-on peroxide-bridged binuclear copper(II) model complexes of relevance to oxyhemocyanin and oxytyrosinase. J. Am. Chem. Soc. 1992, 114, 10421. (b) Pidcock, E.; Obias, H. V.; Abe, M.; Liang, H.-C.; Karlin, K. D.; Solomon, E. I. Spectroscopic and Theoretical Studies of Oxygenated Dicopper(I) Complexes Containing HydrocarbonLinked $\mathrm{Bis}[2-(2$-pyridyl)ethyl]amine Units: Investigation of a Butterfly $\left[\mathrm{Cu}_{2}\left(\mu-\eta^{2}: \eta^{2}\right)\left(\mathrm{O}_{2}\right)\right]^{2+}$ Core. J. Am. Chem. Soc. 1999, 121, 1299.

(29) Ottenwaelder, X.; Rudd, D. J.; Corbett, M. C.; Hodgson, K. O.; Hedman, B.; Stack, T. D. P. Reversible $\mathrm{O}-\mathrm{O}$ bond cleavage in copper-dioxygen isomers: impact of anion basicity. J. Am. Chem. Soc. 2006, 128, 9268.

(30) Funahashi, Y.; Nishikawa, T.; Wasada-Tsutsui, Y.; Kajita, Y.; Yamaguchi, S.; Arii, H.; Ozawa, T.; Jitsukawa, K.; Tosha, T.; Hirota, S.; Kitagawa, T.; Masuda, H. Formation of a Bridged butterfly-type $\mu$ $\eta^{2}: \eta^{2}$-peroxo dicopper core structure with a carboxylate group. J. Am. Chem. Soc. 2008, 130, 16444.

(31) Gagne, R. R.; Koval, C. A.; Lisensky, G. C. Ferrocene as an internal standard for electrochemical measurements. Inorg. Chem. 1980, 19, 2854.

(32) Walton, P. H.; Davies, G. J. On the catalytic mechanisms of lytic polysaccharide monooxygenases. Curr. Opin. Chem. Biol. 2016, 31, 195.

(33) CrysAlis PRO; Agilent Technologies Ltd: Yarnton, Oxfordshire, England, 2013.

(34) Clark, R. C.; Reid, J. S. The analytical calculation of absorption in multifaceted crystals. Acta Crystallogr., Sect. A: Found. Crystallogr. 1995, 51, 887.

(35) (a) Sheldrick, G. M. SHELXT - Integrated space-group and crystal-structure determination. Acta Crystallogr., Sect. A: Found. Adv. 2015, 71, 3. (b) Sheldrick, G. M. Crystal structure refinement with SHELXL. Acta Crystallogr., Sect. C: Struct. Chem. 2015, 71, 3-8.

(36) Farrugia, L. J. WinGX suite for small-molecule single-crystal crystallography. J. Appl. Crystallogr. 1999, 32, 837.

(37) Frisch, M. J.; Trucks, G. W.; Schlegel, H. B.; Scuseria, G. E.; Robb, M. A.; Cheeseman, J. R.; Scalmani, G.; Barone, V.; Petersson, G. A.; Nakatsuji, H.; Li, X.; Caricato, M.; Marenich, A.; Bloino, J.; Janesko, B. G.; Gomperts, R.; Mennucci, B.; Hratchian, H. P.; Ortiz, J. V.; Izmaylov, A. F.; Sonnenberg, J. L.; Williams-Young, D.; Ding, F.; Lipparini, F.; Egidi, F.; Goings, J.; Peng, B.; Petrone, A.; Henderson, T.; Ranasinghe, D.; Zakrzewski, V. G.; Gao, J.; Rega, N.; Zheng, G.; Liang, W.; Hada, M.; Ehara, M.; Toyota, K.; Fukuda, R.; Hasegawa, J.; Ishida, M.; Nakajima, T.; Honda, Y.; Kitao, O.; Nakai, H.; Vreven, T.; Throssell, K.; Montgomery, J. A., Jr.; Peralta, J. E.; Ogliaro, F.; Bearpark, M.; Heyd, J. J.; Brothers, E.; Kudin, K. N.; Staroverov, V. N.; Keith, T.; Kobayashi, R.; Normand, J.; Raghavachari, K.; Rendell, A.; Burant, J. C.; Iyengar, S. S.; Tomasi, J.; Cossi, M.; Millam, J. M.; Klene, M.; Adamo, C.; Cammi, R.; Ochterski, J. W.; Martin, R. L.; Morokuma, K.; Farkas, O.; Foresman, J. B.; Fox, D. J. Gaussian 09, revision A.02; Gaussian, Inc.: Wallingford CT, 2016.

(38) (a) Becke, A. D. Density-functional thermochemistry. III. The role of exact exchange. J. Chem. Phys. 1993, 98, 5648. (b) Lee, C.; Yang, W.; Parr, R. G. Development of the Colle-Salvetti correlationenergy formula into a functional of the electron density. Phys. Rev. B 1988, 37, 785.

(39) Hay, P. J.; Wadt, W. R. Ab initio effective core potentials for molecular calculations. Potentials for $\mathrm{K}$ to $\mathrm{Au}$ including the outermost core orbitals. J. Chem. Phys. 1985, 82, 299.

(40) (a) Hariharan, P. C.; Pople, J. A. The influence of polarization functions on molecular orbital hydrogenation energies. Theor. Chim. Acta. 1973, 28, 213. (b) Francl, M. M.; Petro, W. J.; Hehre, W. J.; Binkley, J. S.; Gordon, M. S.; DeFrees, D. J.; Pople, J. A. Selfconsistent molecular orbital methods. XXIII. A polarization-type basis set for second-row elements. J. Chem. Phys. 1982, 77, 3654.
(41) (a) Tomasi, J.; Persico, M. Molecular Interactions in Solution: An Overview of Methods Based on Continuous Distributions of the Solvent. Chem. Rev. 1994, 94, 2027. (b) Amovilli, C.; Barone, V.; Cammi, R.; Cances, E.; Cossi, M.; Mennucci, B.; Pomelli, C. S.; Tomasi, J. Recent advances in the description of solvent effects with the polarizable continuum model. Adv. Quantum Chem. 1998, 32, 227.

(42) (a) Trasatti, S. The absolute electrode potential: an explanatory note (Recommendations 1986). Pure Appl. Chem. 1986, 58, 955. (b) Persson, I. Solvation and complex formation in strongly solvating solvents. Pure Appl. Chem. 1986, 58, 1153.

(43) Llunell, M.; Casanova, D.; Cirera, J.; Alemany, P.; Alvarez, S. SHAPE, version 2.0; Barcelona, 2010.

(44) McCreery, R. Raman Spectroscopy for Chemical Analysis; John Wiley \& sons, Inc.: New York, 2000; Chapter 10.

(45) https://www.effemm2.de/spectragryph/. 